\title{
Whose Investments in Higher Education Have Been Most \\ Influenced by Labor Market Conditions in Recent Decades?
}

\author{
Dezhi Jiang
}

Northern Illinois University

Department of Economics

Advisor: Professor Virginia Wilcox

January 2022 


\begin{abstract}
Theoretically, high school graduates are more likely to enroll in college during periods of unfavorable labor market conditions because of a lower opportunity cost. However, how this causal relationship has varied in recent decades (from the 1980s to the 2010s), and how the gender and race heterogeneity of this causal effect differs over time are open empirical questions. This research utilizes continuity and a large sample size of the IPUMS Current Population Survey (IPUMS CPS) and finds the causal relationship has increased in recent decades. The estimates also show that the educational decisions of men are generally more sensitive to current labor market conditions than those made by women, but the gap between the sexes is diminishing. Further, the impact of labor market conditions on educational decisions is heterogeneous across race and ethnicity groups as some have been more influenced than others during some decades. Moreover, this research explores a way to use the new information from each year's CPS October Education Supplement survey to update the estimates of this causal effect and compare the estimates to studies using the cohort survey or administrative data.
\end{abstract}

Keywords: human capital, college enrollment, labor market conditions, educational decision JEL classification: E24, E32, I23, I24, J64 


\section{Introduction}

According to human capital theory and enrollment demand theory, human capital investment is countercyclical (Becker, 1990; Clotfelter, 1992). In the case of higher education, people are more likely to enroll in college during economic downturns because of the lowered opportunity cost. Empirically, a large body of studies, including both macro- and micro-level analyses as well as my research of the National Longitudinal Survey of Youth 1997 (NLSY97), provide empirical evidence supporting this theoretical prediction and confirming that either the overall college enrollment level of youth or the likelihood of college enrollment of an individual is increased during recessions or when people are facing unfavorable labor market conditions (ULMCs) (Ayllón and Nollenberger, 2016; Barr and Turner, 2013; Bowlus \& Liu 2003; Dellas and Sakellaris, 2003; Hershbein, 2012; Hillman \& Orians, 2013; Jiang,2019; Long, 2014). However, the research on how this causal relationship varies over time/generation is very limited, and studies on how the gender and race heterogeneity of this causal effect differs over time are even scarcer.

It should be of great interest to school administrators and government policymakers alike to understand whether people's educational decisions become more (or less) responsive to labor market conditions, and which subgroup's college enrollment has been or will be more influenced by labor market conditions. Thus, these stakeholders can reallocate educational resources more efficiently and make policy accordingly.

Previous studies find that the educational decisions of women in the 1970s and the1980s are much less sensitive to current labor market conditions than those of men. According to Hershbein's (2012) study of the National Longitudinal Survey of Youth 1979 (NLSY79), one explanation of this result is the older generation of women are more likely to temporarily move 
into home production when facing ULMCs, which is a less favored option for men. However, starting in the later 1970s, the younger generation of women became more ambitious about their careers. As a result, their demand for higher education has increased since then, which in turn has caused a higher association of their educational decisions with current labor market conditions. Therefore, I expect the younger generation of women will be more likely to enroll in colleges instead of turning to home production during ULMCs.

In the case of minorities, previous studies find that the educational decisions of black individuals are much less sensitive to the changes in labor market conditions than white individuals (Bowlus \& Liu, 2003; Hershbein, 2012). Whether the variation of labor market conditions influences their educational decisions about college enrollment and how this causal effect differs in recent decades are still open empirical questions. Furthermore, research on this topic for the Hispanic population is particularly scant but is starting to attract more attention from researchers. The descriptive study of Fry (2010) points out that the freshman enrollment of Hispanics at postsecondary institutions grew the most among all race/ethnicity groups during the recent 2007-2008 recession. Fry and Taylor (2013) suggest this minority enrollment surge may be a byproduct of demographic change and the greater high school graduation rate of Hispanics since the 1990s. Consequently, whether the educational decisions of Hispanic high school graduates (HSGs) are influenced by variations in the current labor market conditions and how this causal relationship varies in recent decades are also open empirical questions.

In addition, during the Covid-19 pandemic, I have been questioned multiple times about how this causal relationship varies regarding the pandemic. There is no doubt that people tend to increase their human capital investment because of the strong negative labor market shock. On the other hand, people may worry about their own and their family's safety and health. Further, 
they may not like attending online classes or dislike wearing a face mask for in-person classes, either. In sum, the overall impact of the pandemic on human capital investment may be ambiguous. Nonetheless, the underlying concern is how to update the empirical findings of the causal effect of labor market conditions on college enrollment over time or in case of new events like a pandemic. Therefore, another purpose of this research is to explore a way to update the empirical findings on the causal effect of labor market conditions on college enrollment.

A preview of the findings: 1) this empirical study uses the IPUMS Current Population Survey (IPUMS CPS) data and finds the causal effect of labor market conditions on the decisions of higher education investment has become more significant over past decades. 2) The educational decisions of men are generally more sensitive to current labor market conditions than women's decisions during my study period, but the gap between the sexes is diminishing. 3) The impact of labor market conditions on educational decisions is heterogeneous across races/ethnicity groups. Educational decisions of Hispanic and other non-black minorities were more sensitive to current labor market conditions in the 1990s, white students' decisions were more sensitive in the 2000s, and all race/ethnicity groups' decisions become sensitive after 2010.

The paper proceeds as follows. Section 2 describes the data and the process for preparing the analysis sample, Section 3 provides the empirical strategy of this research, Section 4 discusses the results, and Section 5 provides the conclusions. 


\section{Data}

Individual-level empirical studies of this topic often use three types of data:

administrative data, cohort survey data, and census survey data. The estimates of administrative data could accurately show the impact of local labor market conditions on the enrollment of an institution or a group of institutions in a specific region. However, they are usually not accessible to general researchers and may lack representation for the whole U.S. population or some specific subgroups (Cunha \& Miller, 2014; Turner, 2016; Zimmerman, 2014).

On the other hand, cohort survey data usually have rich information on personal characteristics and family background (Haas \& Fosse, 2008). Examples are those focusing on education and labor market outcomes of youth, such as the NLSY79, NLSY97, and the High School \& Beyond (HS\&B). Most importantly, they include measurements of ability such as transcripts or cognitive test scores that are usually not found in other surveys but are crucial factors to predict college enrollment probability (Aughinbaugh, 2005; Kienzl et al., 2007; Light \& Strayer, 1999). Moreover, the longitudinal design of these cohort surveys allows researchers to examine both the short-term impact of labor market conditions on educational decisions and the long-term impacts on educational attainment and labor market outcomes (Bowlus \& Liu, 2003; Hershbein, 2012).

However, cohort survey data are not without shortcomings. First, because of their rich information about personal characteristics and family background, they usually have much higher confidentiality requirements and restrictions than other data sources. For example, the smallest unit of geographic information of the NLSY97 publicly accessible data is the census region (Northeast, North Central, South, and West). As a result, if researchers want to match 
state unemployment rate (UE) to the NLSY97, they must apply for access to the restricted Geocode data from the Bureau of Labor Statistics (BLS).

Second, the sample size of a cohort survey dataset is usually much smaller than that of a national cross-sectional survey or census survey. Again, using the NLSY97 as an example, it has about 9,000 observations in total, however, only about 3,000 of them remain in the analysis sample if I focus on HSGs who were 16-20 years old and not missing critical personal and family control variables (such as ability, family income, and parent's education level). In that NLSY97 analysis sample, respondents graduated/left high school from the year 1997 to 2005. During the same period, the CPS has more than 18,000 valid observations, almost six times the size of the NLSY97 sample.

Third, one cohort survey usually represents only one specific generation (e.g., the NLSY79 for generation X and the NLSY97 for generation Y). However, it is challenging to compare cohort surveys due to design and questionnaire changes over time, even when they are from the same series (Ashworth et al., 2017). For instance, the NLSY79 uses the Armed Services Qualification Test (AFQT) score as a cognitive ability measurement. But the NLSY97 uses the Armed Services Vocational Aptitude Battery (ASVAB) score, a subset of the AFQT. Some processes are needed to make cognitive ability measurements comparable between those two cohorts. ${ }^{1}$ Moreover, there is no new cohort survey data available after 2000 for analyzing the educational decisions of the younger generation. Consequently, cohort survey data sets are not the optimal choice to explore the variation of this causal effect across generations.

Compared to administrative data and cohort data, nationally cross-sectional or census survey data (particularly, the CPS data) are widely adopted in empirical studies of many social

\footnotetext{
${ }^{1}$ An equipercentile mapping that corrects for both testing medium and age at test. (Altonji et al., 2009; 2012)
} 
science fields and are easily accessible to researchers. The public CPS data contains state location information; thus, I can directly match samples to state UEs.

More importantly, one attractive advantage of the CPS is its continuity from its distinctive 4-8-4 design. As this 4-8-4 survey design, the surveyed households are in the sample for four consecutive months, out for eight, and then return for another four months before leaving the sample permanently. Therefore, in theory, each month's survey, including the October Education Supplement Survey contains 50\% same respondents from the same month a year earlier and $50 \%$ of new respondents (The CPS handbook of methods, Current population survey: Overview). That means the CPS contains information on new HSGs and their college enrollment decisions every year. This attribute allows me to show that this causal effect varies over past decades and find whether a specific subgroup is more likely to be influenced in different periods (Dellas \& Sakellaris, 2003).

Of course, census survey data have their shortcomings. The most prominent one for this topic is that the CPS has less in-depth information about personal characteristics and family background than the cohort survey data (particularly, no observation of ability). Nevertheless, the benefit of having a much larger sample size may offset this drawback.

For this research, I analyze samples of the CPS October education supplement survey extracted from the Integrated Public Use Microdata Series CPS (IPUMS CPS). The CPS survey is administered monthly by the U.S. Bureau of the Census to over 65,000 households. The main purpose of the basic monthly survey of the CPS is to gather information about the labor force status of the U.S population, such as labor force, employment, hours of work, earnings, and other demographic and labor force characteristics. 
In addition to the basic monthly survey, the U.S. Bureau of the Census conducts a variety of supplemental surveys from time to time. The annual October education supplement survey is administered with the October basic survey to gather additional information about the school enrollment status of household members aged three and older. Finally, the IPUMS CPS is an integrated set of data from the CPS that provides identically coded or "harmonized" variables across different periods of the CPS, thereby making cross-time comparisons using the CPS data more feasible (Rivera Drew et al., 2014).

Due to data limitations that I explain in the following paragraphs, my analysis sample starts in 1984 and contains observations from 1984-89, 1990-99, 2000-09, and 2010-18 with a sample size of $21,468,25,347,22,112$, and 22,004, respectively. Although the 1980 s cohort data only covers six years, there are significantly more youth in the 1980s, leading to a comparably sized date set as those for later decades. This reflects the demographic trend as the very end of the baby boom generation was turning 17-20 years old in the 1980s. This trend is also observed in the number of respondents who graduate high school in the current year: 1,956 respondents graduate HS in the year 1984, but only 1,337 graduate HS in the year 1994, 1,357 in the year 2004, and 1,117 in the year 2014. Also, the statistics show that the 1980s cohort has more siblings than later cohorts.

The dependent variable of this paper, Enroll_college is constructed from the variable “EDTYPE" of the IPUMS CPS, enrolled type information in the October education supplement survey. $^{2}$ The "EDTYPE" indicates whether the youth are enrolled in college and the institution type (a 2-year or 4-year institution). Enroll_college has a value=1 if the respondent $\mathrm{i}$ is enrolling in either 2-year or 4-year college in the CPS October education supplement survey of a given

\footnotetext{
2 The CPS has another dedicated variable, "SCHLCOLL" which indicates whether respondents are enrolling in high school or college, but it is only available after 1989. While, the enrolled type, "EDTYPE" has been available since 1976.
} 
year t. The statistics show that the 1980s cohort compared to later cohorts, on average, are less likely to enroll in college after graduating high school. For later cohorts, even though the percentage enrolling in college varies year from year, the average percentage across decades is very stable (around 68\%).

In this research, I focus on the impact of labor market conditions (that are indicated by each state's UEs in the March CPS survey of a given year) on higher education enrollment probability of 17-20-years-old HSGs. ${ }^{3}$ However, there is no variable in the IPUMS CPS that allows me to determine the exact year and age when the respondents graduate from high school. The closest information that I find is the variable "EDYRDIP", the year completed high school, which only contains three categories: current year, some previous year, and not in-universe. I determine a respondent is an HSG if he or she answered either graduate high school in current year or some previous year. In the analysis sample, only a few of them, about $3-4 \%$ have graduated high school at age 17 . Therefore, most of the respondents in the analysis sample are 18-20 years old. HSGs aged 19 years outnumber those of ages 18 and 20. This pattern is very stable over past decades.

Despite the configuration of the IPUMS data that allows the comparison of the CPS across time, it still needs caution and further processing to ensure variables are comparable across long periods of time. For instance, the IPUMS CPS does not contain the exact level of family income but separates family income into categories. Thus, it is impossible to simply deflate income by the CPI index and compare levels across time. Further, the number of income

\footnotetext{
${ }^{3}$ There are two benefits of using the March UE of the CPS instead of using annual average UE. First, it representations of labor market conditions prior to enrollment status in the October education supplement survey. Thus, using the March UE avoids the possible endogeneity problem if UE and college enrollment move together due to some unobservable factors. Second, the UE variable of the NLSY79/97 datasets is also constructed using the March CPS survey. Therefore, using the March UE of the CPS is convenient to compare the results of this research to the research using the NLSY79/97 data.
} 
categories varies over time: from 1984 to 2003, the family income variable has 14 categories and is top-coded at $\$ 75,000$, while it has 16 categories and is top-coded at $\$ 150,000$ after 2003 . To make the family income variable comparable over time, I recode the income categories into four quartiles for each year (income_quart).

Furthermore, the CPS is a survey at the household level only, and the recorded family income is the total family income of the surveyed household. However, a small portion of youth is not related to the head of the surveyed household. In such cases, the recorded family income may not be appropriate to associate with their educational decisions. To avoid this problem, I only include children of the head of the surveyed household in my study sample. This relationship is determined by the "relate", relationship to the head of the surveyed household variable of the IPUMS CPS. As a result, the remaining analysis sample contains $99.21 \%, 97.5 \%$, $96.25 \%$, and $94.41 \%$ of 17-20 aged HSGs in the 1980s, 1990s, 2000s, and 2010s, respectively. ${ }^{4}$ However, the "relate" variable does not have a child category before 1984 and the family income variable is not available before 1982 either. Those limitations leave me no choice but to examine samples after 1984 if I want to include family income as a control variable in my model, which is shown in my previous paper, Jiang (2019), and also research by other authors to be one of the most influential factors for predicting college enrollment probability (Belley and Lochner, 2007).

Another concern is that the coding of the mother's education variable, mom_edu is different before and after 1991. Before and in 1991, this variable contains each grade completed, high school diploma or not, and years of college, but without degree information. After 1991, this variable has fewer categories of grades before college, and college degree attainment, but no

\footnotetext{
${ }^{4}$ The Appendix Table A-1 provides the frequency of the relationship to the head of the surveyed household.
} 
years of college completion. ${ }^{5}$ To make mother's education comparable over time, I recode this variable into six categories as (0) none or preschool; (1) grades 1-8; (2) grades 9-11; (3) grades 12 or high school diploma or an equivalent one; (4) one year of college or some college; (5) two or three years of college or Associate's degree; (6) four or more years of college education or Bachelor's degree or higher. The statistics show that the average mother's education is steadily increasing over the past decades.

Another challenge of comparing estimates of the CPS over time is the coding of minority categories are charging from time to time. In particular, there is no category of Hispanic ethnicity in the original coding of the CPS, thus, I cannot compare the estimates of the CPS to the NLSY series. ${ }^{6}$ To solve this issue, I use both the race variable, "race" and the Hispanic origin variable, "hispan" from the original coding of the IPUMS CPS and construct a new race/ethnicity variable in the following process and order: (1) I determine a respondent as white or black as indicated in "race"; (2) as "others/mixed and non-Hispanic" if he or she is not a white nor a black in "race" and not a Hispanic in "hispan"; (3) as Hispanic if he or she reports Hispanic origin in "hispan"; (4) as unknown race if the race/ethnicity is not determined by this process.

The results show that this process can identify more than $99 \%$ of the CPS sample's race after 1984. It is worth noting that "white" and "black" in this newly constructed race/ethnicity variable do not contain people of those who have a Hispanic origin, thus "white" and "black" are actually "non-Hispanic white" and "non-Hispanic black or African American", and "Hispanic" includes respondents of unknown races but with a Hispanic origin. Finally, to check the validity of this constructed variable, I compare its race/ethnicity distribution to the U.S. Census

\footnotetext{
${ }^{5}$ Instead of having each grade attainment as a category, after 1991, the grade categories become grades 1, 2, 3, or 4; grades 5 or 6 ; grades 7 or 8 ; grade 9 ; grade 10 ; grade $11 \ldots$

${ }^{6}$ The race/ethnicity variable of the NLSY series has four categories: Black, Hispanic, Mixed race, and non-

Black/non-Hispanic.
} 
demographics over the past decades, and their distributions are very close. ${ }^{7}$ Lastly, based on the newly constructed race/ethnicity variable, I create the indicator variables white, black, Hispanic, and others for my analysis.

The variable nsibs counts the number of own siblings (including half-siblings, stepsiblings, and adopted siblings) residing with each. According to the statistics, $98.25 \%$ of the analysis sample have four or fewer siblings. The remaining $1.75 \%$ of the samples may be considered as outliers. Because the CPS has a relatively large sample size, a small number of outliers will have a limited impact on estimates. ${ }^{8}$ To include as many samples as possible, I do not apply any restrictions to exclude outliers in this research.

Finally, it is worthwhile to note there are some substantial changes in race/demographics according to the CPS over the past decades: the percentage of non-Hispanic white youth decreased from $80 \%$ in the 1980 s to $62 \%$ in the 2010 s, and the percentage of Hispanic youth increased from $6 \%$ in the 1980 s to $18 \%$ in the 2010 s, while the percentage of others/mixed-race increased from $3 \%$ in the 1980 s to $9 \%$ in the 2010 s, and the percentage of black (African American) almost stayed the same around $10 \%$.

Other variables that I define for my analysis are the individual's sex (female) and the state UE (UE_state) that matches from the BLS database which is constructed from the March CPS survey. Table 1 includes definitions of all variables used in this research. Table 2 reports summary statistics for my study sample.

[Table 1 goes here]

[Table 2 goes here]

\footnotetext{
${ }^{7}$ For reference, the U.S. Census racial/ethnic demographics shows that in 1990, non-Hispanic white, black, Hispanic accounts for $75.6 \%, 12.1 \%$, and $9 \%$ of the whole U.S. population, respectively. In $2000,69.1 \%, 12.3 \%$, and $12.5 \%$. In $2010,63.7 \%, 12.6 \%$, and $16.3 \%$. (U.S. Census Bureau)

${ }^{8}$ The regression results of the sample without respondents with has more than four siblings are not very different from the results of the whole sample. (Available upon request.)
} 


\section{Empirical Strategy}

I consider the following probit analyses to estimate the impact of labor market conditions on the probability of college enrollment of an $\mathrm{HSG}^{9}$ :

$$
{\text { Enroll_college }{ }_{i t(O c t)}=\alpha+\beta U E_{\text {State }}(\mathrm{it}(\mathrm{Mar})}+\gamma X i+\mu
$$

Enroll_college $e^{*}$ is the latent continuous probability of college enrollment, while Enroll_college is the observed enrollment status, which equals to 1 if an individual enrolls in a college (either enroll in a 2 -year college or 4-year university), equals to 0 if not enrolled. $X$ is a vector of personal characteristics and family background factors, including the respondents' age, sex, race/ethnicity, household income quartile, mother's education level, and the number of own siblings in the household. ${ }^{10}$ The key interested independent variable and the indicator of labor market conditions, UE_HSL is the March state UE. My theoretical hypothesis is that a higher UE represents a lower opportunity cost of higher education and thus causes an HSG to have a higher probability of enrolling in college, other things equal. I, therefore, expect $\beta>0$.

This research includes the following estimates of the above-mentioned empirical model.

First, to examine the causal effect of labor market conditions on college enrollment probability and the variations of it, I pool all 17-20-years-old HSGs in each decade and run probit regressions of their college enrollment probability. Second, to identify which subgroup of higher education investment decisions are more likely to be influenced by labor market conditions, I first run regressions by sex, then run regressions by race/ethnicity. Third, to check how this causal effect differs between first-time enrollment and re-enrollment, I regress the sub-sample of

\footnotetext{
${ }^{9}$ The Probit model can be viewed as a latent variable model: Enroll_college* $=\mathrm{X}^{\mathrm{T}} \beta+\mu$, where $\mu \sim \mathrm{N}(0,1)$. We do not observe the continuous probability of college enrollment (Enroll_college*), but $\beta$ can be estimated by maximum likelihood with observed college enrollment status (Enroll_college) and follows these conditions: Enroll_college = 1 if $\mathrm{X}^{\mathrm{T}} \beta+\mu>0$ or Enroll_college $=0$ if $\mathrm{X}^{\mathrm{T}} \beta+\mu<=0$.

${ }^{10}$ Because I suspect that age may have non-linear effects on college enrollment probability, I use age dummies instead of treating age as a continuous variable. I also test to treat age as a continuous variable. The results show that youth of older ages have a significantly lower probability of enrolling in college. (Not reported)
} 
18-years-old HSGs only and compare its results to the whole sample's results. Last, to compare the results of this research to my study of the NLSY97 (Jiang, 2019), I restrict the CPS data set from the year 1997 to 2004, which covers the same period when the youth of the NLSY97 leave/graduate high school. ${ }^{11}$

${ }^{11}$ In Essay one, I consider a respondent as a high school graduate if he/she has completed the $12^{\text {th }}$ grade. 


\section{Results}

\subsection{Main Results}

Column (1) to column (4) of Table 3 present the average marginal effects (AME) on college enrollment probability of the 1980 s cohort, the 1990 s cohort, the 2000 s cohort, and the 2010s cohort, respectively. ${ }^{12}$ Row (1) shows the impact of the state UE on the probability of college enrollment across recent decades. In the 1980s, a one-unit increase of UE causes a $0.382 \%$ decrease in the probability of college enrollment. In the 1990s, this causal effect becomes positive but not statistically significant. However, the variation of UEs becomes more influential in the 2000s and forward: a one-unit increase of UE causes a $0.796 \%$ increase in the probability of enrollment in the 2000s while the effect increases to $1.20 \%$ in the 2010 s.

[Table 3 goes here]

The negative causal effect of UE on college enrollment probability in the 1980s rejects my hypothesis. There are two possible interpretations of this negative causal effect. First, the effect of UE on the probability of enrollment may correlate with being in a specific state. Because the discussion of the heterogeneous effect of labor market conditions on educational decisions across states is beyond the scope of this study, I assume there is no or at least no strong heterogeneous effect of UE on college enrollment across states. However, this assumption may be too strong for the 1980s. If this correlation is present, cluster standard errors (SE) at the state level may mitigate this issue (Abadie et al., 2017). Appendix Tables A3-A5 present estimates with clustered SE, in which the Table A-3 result shows that the negative causal effect of UE in the 1980s becomes not statistically significant after clustering SE. This assumption is largely

\footnotetext{
${ }^{12}$ Throughout this study, average marginal effects (AME) of the probit estimates are presented in results tables.
} 
valid in later decades as clustering SE or not has much less or no impact on the statistical inference of the estimates after the 1980s.

Second, Hershbein (2012) analyzes the NLSY79 and finds that in contrast to men, women who graduate high school in an unfavorable labor market are more likely to substitute into house production instead of entering the labor market or enrolling in college. ${ }^{13}$ My estimated effect of UE on college enrollment by sex in Table 4 shows that females HSGs in the 1980s are indeed less likely to enroll in college if facing ULMCs.

In summary, a higher UE has a weak negative impact on college enrollment in the 1980s. This may be contributed by the choice of female HSGs in the 1980s. Nevertheless, this causal effect becomes positive in the 1990s and becomes increasingly significant in later decades.

The estimated effect of age groups indicates there are some non-linear effects, but in general, older HSGs are less likely to enroll in college. Family income is crucial for educational decisions with increasing influence power before the 1990s. This finding is consistent with Belley and Lochner (2007), who compare the NLSY79 to the NLSY97 and find the effects of family income on college attendance increase substantially. However, the results of my analysis indicate that family income does not become more important after the 1990s. This may reflect the trend of greater reliance on student loans to finance higher education among younger cohorts. On the other hand, despite mothers' educational attainment increasing over time, its influence on the human capital investment of children steadily decreases over the decades. Having more siblings in a household only has a significant negative impact on college enrollment in the 1980s. This result holds after clustered SEs at the state level as shown in Table A-3. Finally, black and Hispanics HSGs have become more likely to enroll in college over time.

\footnotetext{
${ }^{13}$ Respondents of the NLSY79 were aged 14-22 in 1979 and were aged 19-27 in 1984. Therefore, the CPS samples of the 1980s are partially comparable to that of the NLSY79.
} 
Next, I turn to the estimates by sex. Summary statistics by sex are in Appendix Table A-2. According to the statistics, throughout all periods, female HSGs come from families with slightly lower socioeconomic status (lower average family income quartile and mother's educational attainment) than male HSGs. Female HSGs also have slightly more siblings than male HSGs. These differences appear to occur because the sample of female HSGs contains more minority individuals and minority women are more likely to graduate from high school than minority men (Greene \& Winters, 2006; Murnane, 2013).

Table 4 shows the estimated AMEs on college enrollment probability by sex across decades. The first row of Table 4 shows the estimated effect of state UE on college enrollment, the odd columns present estimates for male HSGs while the even columns present results for female HSGs. Two findings are worth noting: Firstly, as aforementioned, only female HSGs in the 1980s are less likely to enroll in college if facing ULMCs. However, the effect reverses, and its magnitude and statistical significance increase in later decades. In detail, a one-unit increase of UE causes a $0.605 \%$ increase in college enrollment probability of female HSGs in the 2000s, but the effect increases to $1.06 \%$ in the 2010 s and becomes more statistically significant. Secondly, although younger cohorts of female HSGs are more likely to enroll in college during economic downturns than older generations, their educational decisions are still less influenced by current labor market conditions than those of male HSGs. However, the gap between the sexes diminishes over time.

[Table 4 goes here]

Another interesting finding is that the educational decisions of male HSGs are slightly more influenced by family income and mother's educational attainment than their counterparts across all periods. Except in the 1980s, mother's educational attainment has more influence on 
the educational decisions of female HSGs than that of male HSGs as shown in columns (1) and (2). However, this is reversed in all later decades.

Finally, Table 5 shows the estimated marginal effects on the probability of college enrollment for different race/ethnicity groups across decades. The first row of each sub-table shows the effect of UE on college enrollment among race/ethnicity groups over time. As shown in the first sub-table of the 1980s, white and Hispanic HSGs are less likely to enroll in college if face high UEs in the 1980s. However, the results show that the college enrollment probability of Hispanics and Others (other/mixed race/non-Hispanic) is more sensitive to UE in the 1990s. In that period, a one-unit increase in UE causes more than a $2 \%$ increase in the probability of college enrollment of Hispanic and other/mixed racial HSGs. On the other hand, the college enrollment probability of white and other race HSGs is more likely to be influenced by UE in the 2000s. Lastly, I find that the college enrollment of all race/ethnicity groups becomes more sensitive to labor market conditions after 2010, the post-Great Recession era.

[Table 5 goes here]

\subsection{The Effect on 18-years-old HSGs}

The estimated effects of UE on college enrollment in Tables 3 through 5 represent the total effect that consists of both the effect on first-time college enrollment and the effect on reenrollment. However, the effect of UE on college enrollment may differ between those two enrollment types. Unfortunately, there is no information from the CPS education supplement survey that can be used to determine those two enrollment types.

To explore whether the effect is different for first-time college enrollment vs. reenrollment, I consider the following alternative empirical strategy. Because the statistics of the 
whole sample indicate that only about $3-4 \%$ of respondents have graduated high school at the age of 17, the estimated causal effect of state UE on college enrollment of 18-years-old HSGs is very close to its net effect on first-time enrollment probability. As a result, by comparing the subsample of 18-years-old HSGs to the whole sample, I can disentangle the difference in the effect between enrollment types.

Table 6 reports summary statistics for this sub-sample. Compared to the whole sample, 18-years-old HSGs have a much higher probability of enrolling in college. Nonetheless, there is no significant statistical difference regarding personal characteristics and family background between the main sample and the sub-sample of 18-year-old HSGs.

[Table 6 goes here]

The first row of Table 7 shows the estimated effect of UE on college enrollment probability of 18-year-old HSGs across past decades. A comparison of the results of Table 7 to the results of Table 3 shows that the causal effect of UE on 18-year-old HSGs is weaker than its effect on the whole sample. Consequently, this causal effect is stronger on older HSGs and presumably on re-enrollment HSGs as well. This finding is consistent with my NLSY97 study, in which I find labor market conditions have a much stronger impact on college enrollment one year after leaving high school than in the year when students leave high school.

[Table 7 goes here]

\subsection{Comparison to the NLSY97}

In Jiang (2019), I find HSGs in the NLSY97 have a higher probability of enrolling in college if they leave high school during ULMCs. For comparability of results, it is important to check whether this result holds when using the constructed CPS data covering the same period. 
Moreover, using the CPS presumably provides more precise estimates of any effects on college enrollment because of its much larger sample size.

Treating the NLSY97 as cross-sectional and pooling all 17-20-year-old HSGs who are not missing other family background variables results in 9,234 valid observations of HSGs from 1997 to 2005 . During this same period, the CPS contains 18,894 valid observations. Table 8 shows the summary statistics of the comparable samples of the NLSY97 and the constructed CPS during the same period.

[Table 8 goes here]

According to the summary statistics, there are some significant differences between those two surveys. First, as shown in Table 8, the CPS contains fewer black and Hispanic respondents than the NLSY97. This is because the CPS categorizes more minorities into "other" races, while the NLSY97 does not have a category for "other" and very few respondents are categorized as "mixed-race". Since the "mixed race" sample of the NLSY97 is too small (83 out of 8,984), most of the previous studies exclude them from their analysis. I also follow this strategy. On the other hand, to make the CPS more comparable to the NLSY97, I exclude the "other" race category in this comparison section.

Second, those two data sets use different state UEs. The UE of the NLSY97 "provides the unemployment rate for the respondent's metropolitan area, if applicable, or the balance of the respondent's state" (Introduction to NLSY97 Geocode Data). In contrast, the CPS uses state average UEs that are constructed from the CPS basic survey. This difference explains the higher average UE in the NLSY97 data and its higher variation as well.

Additionally, the major problem that prevents me from comparing the results of the NLSY97 and the CPS is because they have very different survey designs. The NLSY97 is a 
longitudinal survey (long panel), which interviews the same respondents annually from 1997 to 2011 and biennially since then. Therefore, I cannot pool the NLSY97 and implement the same empirical strategy as I use for the CPS. On the contrary, pooling the CPS sample is a sounder statistical practice, as its 4-8-4 design is close to an annual cross-sectional design. Indeed, most empirical studies use the CPS as annual cross-sectional data. Only recently have researchers started to explore its longitudinal usage (Rivera Drew et al., 2014).

Because of their survey design differences, the statistics of the time-varying variables could differ significantly between these two data sets. For instance, as time passes, the NLSY97 HSGs are growing older and becoming less likely to enroll in college. Thus, in pooling the NLSY97 17-20-year-old HSGs together, the mean age is greater than the CPS sample of the same period. While their mean probability of enrolling in college, Enroll_college is 54\%, which is much lower than that of the CPS. ${ }^{14}$

Nevertheless, the statistics of time-invariant variables between the sample of the NLSY97 and the CPS, such as family income quartiles, income_quart, and mother's education level, mom_edu, indicate they come from similar families. ${ }^{15}$

Following the same empirical strategy that I described in section 3, the first row of Table 9 shows the estimated effects of labor market conditions on the college enrollment probability of 17-20-year-old HSGs from the 1997-2005 CPS. As column (1) shows, on average a one-unit increase of state UE causes about a $1 \%$ increase in the probability of college enrollment across all HSGs. By comparing the results between columns (2) and (3), educational decisions of male HSGs are slightly more sensitive than that of females regarding current labor market conditions.

\footnotetext{
${ }^{14}$ Other factors, such as sample selection and response rate may also contribute to this difference between the NLSY97 and the CPS.

15 The household member under age 18, HHunder18_1997 variable of the NLSY97 includes the respondents themselves since they were ages 12 to 16 as of December 31, 1996. With that in mind, the statistics of this variable is also very close to nsibs, the number of siblings of the CPS.
} 
[Table 9 goes here]

Columns (4) - (6) show the effects of UE on educational decisions among race/ethnicity groups from 1997 to 2005 . The estimates show that the educational decisions of Hispanic HSGs respond more than white or black to poorer labor market conditions. This provides preliminary empirical evidence for answering the question of Fry (2010). In comparison, the educational decisions of white HSGs are also significantly influenced by labor market conditions, similarly seen in the 2000s and 2010s as shown in Table 5. Lastly, the educational decisions of black HSGs are not sensitive to the variation of labor market conditions as much as in earlier decades. However, as mentioned in section 4-1 and shown in Table 5, their educational decisions start to be strongly impacted by labor market conditions in the 2010 s.

Overall, the findings of this 1997-2005 CPS are close to the results for the 1990s and the 2000s CPS that are discussed in section 4-1. Due to the survey design difference between the NLSY97 and the CPS, I must use different empirical strategies. As a result, I am not able to directly compare the 1997-2005 CPS and the NLSY97. ${ }^{16}$ Nonetheless, the findings of the 19972005 CPS are close to those of the NLSY97. Both confirm that HSGs are more likely to enroll in college if they face ULMCs.

\subsection{2-year Colleges vs. 4-year Universities}

Because it is not the main purpose of this research to explore the heterogeneity of the effects between 2-year colleges and 4-year universities, I did not conduct a separate analysis between them in section 4-1. However, labor market conditions may have disproportional impacts on the

\footnotetext{
${ }^{16}$ In detail, in Jiang (2019), I estimate the effect of local labor market conditions when leaving high school on college enrollment one year later. However, due to the lack of information on the high school graduation date in the CPS, I cannot implement the same empirical strategy for this research. On the other hand, because the NLSY97 is a longitudinal survey, the estimates would be biased if I pool the respondents together as I treat the CPS in this research.
} 
enrollment of 2-year colleges and 4-year universities. To examine the possible different effects between the two institution types, I use the 1997-2005 CPS and conduct a simply multinomial logistic analysis that estimates effects of labor market conditions on the probabilities of (1) enrolling in a 2-year college, (2) a 4-year university, or (3) not enrolling (the base group).

I also separate the analysis into current year HSGs and previous HSGs, since it may be that current labor market conditions have different effects on the choice of institution for these two groups. The two-way frequencies reported in Table 10 show that about one-third of enrolled students are current year HSGs and about 19\%, 49\%, and 32\% are enrolled in a 2-year college, 4-year universities, and not enrolled, respectively.

[Table 10 goes here] [Table 11 goes here]

Table 11 reports the multinomial logistic estimated effects, in which column (1) shows the estimated effect on the whole sample that indicates the enrollment of 2-year colleges indeed are more influenced by current labor market conditions than that of 4-year universities. Furthermore, columns (2) and (3) show that labor market conditions have a significant impact on 2-year college enrollment probabilities of both current year HSGs and previous years HSGs. However, labor market conditions only have a strong impact on 4-year college enrollment probabilities of current year HSGs but not on that of previous years HSGs. Lastly, the heterogeneous effects between institution types may be more substantial for minority HSGs than white HSGs, which requires further theoretical developments and more sophisticated empirical investigations. 


\section{Discussion and Conclusion}

This study finds that the causal effect of labor market conditions on the decision to enroll in higher education has varied in recent decades. First, the impact has become more significant in terms of both the magnitude and the statistical significance of the estimates. Second, the gender heterogeneity of this causal effect differs significantly over time. The educational decisions of male HSGs are generally more sensitive to current labor market conditions than female HSGs, but the influence gap between sexes is diminishing as the educational decisions of female HSGs have become more and more sensitive to labor market conditions in recent decades. Third, the race heterogeneity of this causal effect also differs significantly over time as the educational decisions of Hispanic HSGs in the 1990s and white HSGs in the 2000s were more sensitive to labor market conditions, while the educational decisions of all race/ethnicity groups became more sensitive to labor market conditions after the Great Recession.

The analysis reported here provides empirical evidence that the increasing influence of labor market conditions on educational decisions over time is due to the increasing demand for higher education by women and minorities and thus the higher importance of labor market conditions on their educational decisions. However, this research does not explore or explain why some race/ethnicity groups are more sensitive to the labor market conditions than others in some specific time periods. For example, some interesting questions for future research would be: why do the educational decisions of Hispanic HSGs exhibit cyclical behavior respecting to labor market conditions (e.g., education decisions of Hispanics HSGs were sensitive to labor market conditions in the 1990s, but not in the 2000s, and again were sensitive in 2010s)? Why did the educational decisions of black HSGs become sensitive to labor market conditions in the 2010s but not before? Is that because of the profound impacts of the Great Recession and thus their 
educational decisions only respond to such severe circumstances rather than modest economic downturns as other groups do? Or do the educational decisions of black become more responsive to labor market conditions after all as others do?

This research has other limitations. First, it is largely sound to use state average UEs as the indicator for labor market conditions to explore their overall causal effect on the educational decisions of HSGs. However, college decisions are presumably more associated with the UE of the young population compared to the UE of the whole labor force. Thus, using the UE of teenagers and those in their early twenties as the indicator for labor market conditions may provide more precise estimates. Second, the educational decisions of minorities may also be more influenced by their specific groups' UEs. Third, the estimated effects of minorities may be more sensitive to locational controls since they are less likely to locate randomly as compared to white; thus, their estimates may suffer more aggregation bias from using state-level UE. Accordingly, the findings of this analysis provide only preliminary empirical evidence for minorities, and more sophisticated analyses are needed to explore how their educational decisions are influenced by current labor market conditions.

Notwithstanding, the findings imply that administrators of higher education institutions and policymakers of state/federal governments should expect a higher variation in higher education demands caused by variation in labor market conditions in the future. Pissarides (2011) argues that governments could consider providing support for people to enroll in regular education as a tool of counter-cyclical employment policy. Indeed, Barr and Turner (2015) find that states that have more inclusive approved training laws of unemployment insurance (more programs are included, and the unemployed will not forfeit their unemployment benefits after 
enrolling in those programs) observe more unemployed people enroll in colleges during recessions.

Considering that people whose educational decisions are influenced by the labor market conditions are most likely to be at the margin of more schooling. Zimmerman (2014) finds that their private return for more education is not less than traditional college-bound students. Plus, there is considerable social benefit from a more educated labor force (Oreopoulos \& Salvanes, 2011). Altogether, it is a good investment for the government to offer more financial support to people who want to accumulate more human capital during economic downturns, rather than transferring the financial burden to students as student loans. Unfortunately, what has been observed so far is "the Great Recession has accelerated the cost-shifting from public subsidies to individual payments in higher education" (Barr \& Turner, 2013, p. 1). 


\section{REFERENCES}

Abadie, A., Athey, S., Imbens, G. W., \& Wooldridge, J. (2017). When should you adjust standard errors for clustering? (Working Paper No. 24003; Working Paper Series). National Bureau of Economic Research. https://doi.org/10.3386/w24003

Altonji, J. G., Bharadwaj, P., \& Lange, F. (2009). Constructing AFQT scores that are comparable across the NLSY79 and the NLSY97. Yale University.

Altonji, J. G., Bharadwaj, P., \& Lange, F. (2012). Changes in the characteristics of American youth: Implications for adult outcomes. Journal of Labor Economics, 30(4), 783-828.

Ashworth, J., Hotz, V. J., Maurel, A., \& Ransom, T. (2017). Changes across cohorts in wage returns to schooling and early work experiences (No. 11231). Institute of Labor Economics (IZA).

Aughinbaugh, A., Pierret, C. R., \& Rothstein, D. S. (2005). The impact of family structure transitions on youth achievement: Evidence from the children of the NLSY79. Demography, 42(3), 447-468.

Ayllón, S., \& Nollenberger, N. (2016). Are recessions good for human capital accumulation? NEGOTIATE Working Paper No. 5.1. NEGOTIATE: Overcoming Early Job-Insecurity in Europe

Barr, A., \& Turner, S. E. (2013). Expanding enrollments and contracting state budgets: The effect of the Great Recession on higher education. The ANNALS of the American Academy of Political and Social Science, 650(1), 168-193.

Barr, A., \& Turner, S. (2015). Out of work and into school: Labor market policies and college enrollment during the Great Recession. Journal of Public Economics, 124, 63-73.

Becker, W. (1990). The demand for higher education. In S. Hoenack \& E. Collins (Eds.), The economics of American universities: Management, operations, and fiscal environment (pp. 155188). State University of New York.

Belley, P., \& Lochner, L. (2007). The changing role of family income and ability in determining educational achievement. Journal of Human capital, 1(1), 37-89.

Bowlus, A. J., \& Liu, H. (2003). The long-term effects of graduating from high school during a recession: Bad luck or forced opportunity? (No. 20037). University of Western Ontario, Centre for Human Capital and Productivity (CHCP). 
Clotfelter, C. T. (1992). Explaining the demand. In C. Clotfelter, R. Ehrenberg. M. Getz, \& J. Siegfried (Eds.), Economic challenges in higher education (pp. 59-88). University of Chicago Press.

Cunha, J. M., \& Miller, T. (2014). Measuring value-added in higher education: Possibilities and limitations in the use of administrative data. Economics of Education Review, 42, 64-77.

Dellas, H., \& Sakellaris, P. (2003). On the cyclicality of schooling: Theory and evidence. oxford Economic papers, 55(1), 148-172.

Fry, R. (2010). Minorities and the recession-era college enrollment boom. Washington, DC: Pew Research Center Social and Demographic Trends Project.

Fry, R., \& Taylor, P. (2013). Hispanic high school graduates pass Whites in rate of college enrollment. Washington DC: Pew Research Center, $13 p$.

Greene, J. P., \& Winters, M. A. (2006). Leaving boys behind: Public high school graduation rates. Education Working Paper Archive.

Haas, S. A., \& Fosse, N. E. (2008). Health and the educational attainment of adolescents: Evidence from the NLSY97. Journal of health and social behavior, 49(2), 178-192.

Hershbein, B. J. (2012). Graduating high school in a recession: Work, education, and home production. The BE journal of economic analysis \& policy, 12(1).

Hillman, N. W., \& Orians, E. L. (2013). Community colleges and labor market conditions: How does enrollment demand change relative to local unemployment rates? Research in Higher Education, 54(7), 765-780.

Introduction to NLSY97 Geocode Data. (n.d.). U.S. Bureau of Labor Statistics. Retrieved September 28, 2021, from https://www.nlsinfo.org/content/cohorts/nlsy97/other-documentation/geocodecodebook-supplement/introduction-nlsy97-geocode

Jiang, D. (2019). Impact of local market condition on human capital investment of higher education, evidence from the NLSY97. Working paper. Northern Illinois University.

Kienzl, G. S., Alfonso, M., \& Melguizo, T. (2007). The effect of local labor market conditions in the 1990s on the likelihood of community college students' persistence and attainment. Research in Higher Education, 48(7), 751-774 
Light, A., \& Strayer, W. (2000). Determinants of college completion: School quality or student ability?. Journal of Human resources, 299-332.

Long, B. T. (2014). The financial crisis and college enrollment: How have students and their families responded? In J. R. Brown \& C. M. Hoxby (Eds.), How the financial crisis and Great Recession affected higher education (pp. 209-233). University of Chicago Press.

Murnane, R. J. (2013). US high school graduation rates: Patterns and explanations. Journal of Economic Literature, 51(2), 370-422.

Oreopoulos, P., \& Salvanes, K. G. (2011). Priceless: The nonpecuniary benefits of schooling. Journal of Economic perspectives, 25(1), 159-84.

Pissarides, C. A. (2011). Regular education as a tool of counter-cyclical employment policy. Nordic Economic Policy Review, 1(2011), 209-232.

Rivera Drew, J. A., Flood, S., \& Warren, J. R. (2014). Making full use of the longitudinal design of the Current Population Survey: Methods for linking records across 16 months. Journal of economic and social measurement, 39(3), 121-144.

Sarah F., Miriam K., Renae R., Steven R., \& J. Robert W. Integrated Public Use Microdata Series, Current Population Survey: Version 8.0 [dataset]. Minneapolis, MN: IPUMS, 2020.

Turner, L. J. (2016). The returns to higher education for marginal students: Evidence from Colorado welfare recipients. Economics of Education Review, 51, 169-184.

Unemployment Rates for States. (2021, September 17). Retrieved January 15, 2019, from https://www.bls.gov/web/laus/laumstrk.htm.

U.S. Bureau of Labor Statistics. (2018, April 1). Current population survey: Overview. U.S. Bureau of Labor Statistics. Retrieved September 29, 2021, from https://www.bls.gov/opub/hom/cps/home.htm.

Zimmerman, S. D. (2014). The returns to college admission for academically marginal students. Journal of Labor Economics, 32(4), 711-754. 


\section{Table 1 Variable Definitions}

\begin{tabular}{ll}
\hline variable name & variable label \\
\hline Enroll_college & $=1$ if individual is enrolled in 2- or 4-year college; else $=0$ \\
UE_state & State unemployment rate \\
age & Age in years \\
age_17 & $=1$ if age is $17 ;$ else $=0$ \\
age_18 & $=1$ if age is $18 ;$ else $=0$ \\
age_19 & $=1$ if age is $19 ;$ else $=0$ \\
age_20 & $=1$ if age is $20 ;$ else $=0$ \\
income_quart & Family income quartiles in each year \\
mom_edu & Mother's education level \\
nsibs & Numbers of own siblings in household \\
female & $=1$ if individual is woman; else $=0$ \\
white & $=1$ if individual is white; else $=0$ \\
black & $=1$ if individual is black; else $=0$ \\
hispanic & $=1$ if individual is Hispanic; else $=0$ \\
others & $=1$ if individual is other $/$ mixes $/$ non-Hispanic; else $=0$ \\
\hline
\end{tabular}


Table 2 Summary Statistics

\begin{tabular}{lrrrrr} 
1984-1989 & Obs & Mean & Std. Dev. & Min & Max \\
\hline Variable & 21468 & .58 & .49 & 0 & 1 \\
\hline Enroll college & 21468 & 6.52 & 2.07 & 2.2 & 15.2 \\
UE state & 21468 & 18.91 & .88 & 17 & 20 \\
age & 21468 & .04 & .2 & 0 & 1 \\
age 17 & 21468 & .32 & .47 & 0 & 1 \\
age 18 & 21468 & .34 & .47 & 0 & 1 \\
age 19 & 21468 & .3 & .46 & 0 & 1 \\
age 20 & 21468 & 2.93 & 1.02 & 1 & 4 \\
income quart & 21468 & 3.62 & 1.41 & 0 & 6 \\
mom edu & 21468 & 1.41 & 1.25 & 0 & 9 \\
nsibs & 21468 & .51 & .5 & 0 & 1 \\
female & 21468 & .8 & .4 & 0 & 1 \\
white & 21468 & .11 & .31 & 0 & 1 \\
black & 21468 & .06 & .23 & 0 & 1 \\
hispanic & 21468 & .03 & .18 & 0 & 1 \\
others & & & & & \\
\hline
\end{tabular}

\begin{tabular}{lrrrrr} 
1990-1999 & Obs & Mean & Std. Dev. & Min & Max \\
\hline Variable & 25347 & .67 & .47 & 0 & 1 \\
\hline Enroll college & 25347 & 5.83 & 1.61 & 2.4 & 11.5 \\
UE state & 25347 & 18.94 & .86 & 17 & 20 \\
age & 25347 & .03 & .17 & 0 & 1 \\
age 17 & 25347 & .31 & .46 & 0 & 1 \\
age 18 & 25347 & .35 & .48 & 0 & 1 \\
age 19 & 25347 & .31 & .46 & 0 & 1 \\
age 20 & 25347 & 2.96 & 1.01 & 1 & 4 \\
income quart & 25347 & 3.91 & 1.42 & 0 & 6 \\
mom edu & 25347 & 1.27 & 1.16 & 0 & 9 \\
nsibs & 25347 & .51 & .5 & 0 & 1 \\
female & 25347 & .76 & .42 & 0 & 1 \\
white & 25347 & .1 & .31 & 0 & 1 \\
black & 25347 & .08 & .27 & 0 & 1 \\
hispanic & 25347 & .05 & .22 & 0 & 1 \\
others & & & & 0 \\
\hline
\end{tabular}

(continued on the following page) 
(Table 2 continued)

\begin{tabular}{lrrrrr}
$2000-2009$ & Obs & Mean & Std. Dev. & Min & Max \\
\hline Variable & 22112 & .68 & .46 & 0 & 1 \\
\hline Enroll college & 22112 & 5.21 & 1.59 & 2.4 & 12.9 \\
UE state & 22112 & 18.94 & .85 & 17 & 20 \\
age & 22112 & .03 & .16 & 0 & 1 \\
age 17 & 22112 & .31 & .46 & 0 & 1 \\
age 18 & 22112 & .36 & .48 & 0 & 1 \\
age 19 & 22112 & .31 & .46 & 0 & 1 \\
age 20 & 22112 & 2.88 & 1.01 & 1 & 4 \\
income quart & 22112 & 4.21 & 1.42 & 0 & 6 \\
mom edu & 22112 & 1.25 & 1.11 & 0 & 9 \\
nsibs & 22112 & .5 & .5 & 0 & 1 \\
female & 22112 & .73 & .45 & 0 & 1 \\
white & 22112 & .09 & .29 & 0 & 1 \\
black & 22112 & .11 & .32 & 0 & 1 \\
hispanic & 22112 & .07 & .25 & 0 & 1 \\
others & & & & & \\
\hline
\end{tabular}

\begin{tabular}{|c|c|c|c|c|c|}
\hline Variable & Obs & Mean & Std. Dev. & Min & $\operatorname{Max}$ \\
\hline Enroll college & 22004 & .68 & .47 & 0 & 1 \\
\hline UE state & 22004 & 6.64 & 2.35 & 2.3 & 13.5 \\
\hline age & 22004 & 18.96 & .87 & 17 & 20 \\
\hline age 17 & 22004 & .04 & .18 & 0 & 1 \\
\hline age 18 & 22004 & .29 & .46 & 0 & 1 \\
\hline age 19 & 22004 & .35 & .48 & 0 & 1 \\
\hline age 20 & 22004 & .32 & .47 & 0 & 1 \\
\hline income quart & 22004 & 2.77 & 1.02 & 1 & 4 \\
\hline mom edu & 22004 & 4.33 & 1.48 & 0 & 6 \\
\hline nsibs & 22004 & 1.3 & 1.15 & 0 & 9 \\
\hline female & 22004 & .5 & .5 & 0 & 1 \\
\hline white & 22004 & .62 & .49 & 0 & 1 \\
\hline black & 22004 & .1 & .31 & 0 & 1 \\
\hline hispanic & 22004 & .18 & .39 & 0 & 1 \\
\hline others & 22004 & .09 & .29 & 0 & 1 \\
\hline
\end{tabular}

Source: IPUMS CPS; Bureau of Labor Statistics

Including samples who were age 17-20 years old, graduated high school, and a child related to the head of the surveyed household. 
Table 3 Effect of State Unemployment Rate on College Enrollment Probability

\begin{tabular}{|c|c|c|c|c|}
\hline & $\begin{array}{r}(1) \\
84-89\end{array}$ & $\begin{array}{r}(2) \\
90-99\end{array}$ & $\begin{array}{r}(3) \\
00-09\end{array}$ & $\begin{array}{r}(4) \\
10-18\end{array}$ \\
\hline UE_state & $\begin{array}{c}-0.00382 * * \\
(0.012)\end{array}$ & $\begin{array}{l}0.00148 \\
(0.395)\end{array}$ & $\begin{array}{l}0.00796 * * * \\
(0.000)\end{array}$ & $\begin{array}{l}0.0120 * * * \\
(0.000)\end{array}$ \\
\hline age_18 & $\begin{array}{l}0.0629 * * * \\
(0.000)\end{array}$ & $\begin{array}{l}0.00317 \\
(0.855)\end{array}$ & $\begin{array}{l}0.138^{* * *} \\
(0.000)\end{array}$ & $\begin{array}{l}0.0919 * * * \\
(0.000)\end{array}$ \\
\hline age_19 & $\begin{array}{r}0.0174 \\
(0.296)\end{array}$ & $\begin{array}{l}-0.0436^{* *} \\
(0.011)\end{array}$ & $\begin{array}{c}0.107 * * * \\
(0.000)\end{array}$ & $\begin{array}{l}0.0617^{* * *} \\
(0.000)\end{array}$ \\
\hline age_20 & $\begin{array}{l}-0.0382 * * \\
(0.022)\end{array}$ & $\begin{array}{l}-0.0772^{* * *} \\
(0.000)\end{array}$ & $\begin{array}{l}0.0759 * * * \\
(0.000)\end{array}$ & $\begin{array}{r}0.0245 \\
(0.133)\end{array}$ \\
\hline 2. income_quart & $\begin{array}{l}0.0415^{* * *} \\
(0.001)\end{array}$ & $\begin{array}{l}0.0386^{* * *} \\
(0.001)\end{array}$ & $\begin{array}{l}0.0616^{* * *} \\
(0.000)\end{array}$ & $\begin{array}{r}0.0138 \\
(0.195)\end{array}$ \\
\hline 3.income_quart & $\begin{array}{l}0.0834 * * * \\
(0.000)\end{array}$ & $\begin{array}{l}0.103^{* * *} \\
(0.000)\end{array}$ & $\begin{array}{l}0.130 * * * \\
(0.000)\end{array}$ & $\begin{array}{l}0.0699 * * * \\
(0.000)\end{array}$ \\
\hline 4. income_quart & $\begin{array}{c}0.174 * * * \\
(0.000)\end{array}$ & $\begin{array}{c}0.204 * * * \\
(0.000)\end{array}$ & $\begin{array}{l}0.211 * * * \\
(0.000)\end{array}$ & $\begin{array}{l}0.165^{* * *} \\
(0.000)\end{array}$ \\
\hline mom_edu & $\begin{array}{l}0.0936 * * * \\
(0.000)\end{array}$ & $\begin{array}{l}0.0747^{* * *} \\
(0.000)\end{array}$ & $\begin{array}{l}0.0668^{* * *} \\
(0.000)\end{array}$ & $\begin{array}{l}0.0618^{* * *} \\
(0.000)\end{array}$ \\
\hline nsibs & $\begin{array}{l}-0.0100 * * * \\
(0.000)\end{array}$ & $\begin{array}{r}0.000524 \\
(0.827)\end{array}$ & $\begin{array}{r}0.000603 \\
(0.819)\end{array}$ & $\begin{array}{r}-0.000672 \\
(0.795)\end{array}$ \\
\hline female & $\begin{array}{l}0.0504 * * * \\
(0.000)\end{array}$ & $\begin{array}{l}0.0878^{* * *} \\
(0.000)\end{array}$ & $\begin{array}{c}0.111 * * * \\
(0.000)\end{array}$ & $\begin{array}{l}0.108^{* * *} \\
(0.000)\end{array}$ \\
\hline black & $\begin{array}{l}-0.0606 * * * \\
(0.000)\end{array}$ & $\begin{array}{l}-0.0488^{* * *} \\
(0.000)\end{array}$ & $\begin{array}{l}-0.0230 * * \\
(0.025)\end{array}$ & $\begin{array}{l}-0.0168^{*} \\
(0.092)\end{array}$ \\
\hline hispanic & $\begin{array}{r}0.0221 \\
(0.104)\end{array}$ & $\begin{array}{l}0.0339 * * * \\
(0.001)\end{array}$ & $\begin{array}{l}0.00293 \\
(0.760)\end{array}$ & $\begin{array}{l}0.0670 * * * \\
(0.000)\end{array}$ \\
\hline others & $\begin{array}{l}0.0853^{* * *} \\
(0.000)\end{array}$ & $\begin{array}{l}0.0720^{* * *} \\
(0.000)\end{array}$ & $\begin{array}{l}0.0462^{* * *} \\
(0.000)\end{array}$ & $\begin{array}{l}0.0563 * * * \\
(0.000)\end{array}$ \\
\hline $\mathrm{N}$ & 21468 & 25347 & 22112 & 22004 \\
\hline
\end{tabular}

p-values in parentheses

Source: IPUMS CPS

Including samples who were age 17-20 years old, graduated high school, and a child related to the head of a household.

Estimated by Probit and average marginal effect (AME) are reported.

State UE Effect on College Enrollment

$* \mathrm{p}<\theta .10, * * \mathrm{p}<0.05, * * * \mathrm{p}<\theta .010$ 
Table 4 Effect of State Unemployment Rate on College Enrollment Between the Sex

\begin{tabular}{|c|c|c|c|c|c|c|c|c|}
\hline & $\begin{array}{r}(1) \\
84-89 M\end{array}$ & $\begin{array}{r}(2) \\
84-89 \mathrm{~F}\end{array}$ & $\begin{array}{r}(3) \\
90-99 M\end{array}$ & $\begin{array}{r}(4) \\
90-99 \mathrm{~F}\end{array}$ & $\begin{array}{r}(5) \\
00-09 M\end{array}$ & $\begin{array}{r}(6) \\
00-09 \mathrm{~F}\end{array}$ & $\begin{array}{r}(7) \\
10-18 M\end{array}$ & $\begin{array}{r}(8) \\
10-18 \mathrm{~F}\end{array}$ \\
\hline UE_state & $\begin{array}{r}-0.00268 \\
(0.221)\end{array}$ & $\begin{array}{c}-0.00489 * * \\
(0.021)\end{array}$ & $\begin{array}{l}0.00433^{*} \\
(0.088)\end{array}$ & $\begin{array}{r}-0.00131 \\
(0.579)\end{array}$ & $\begin{array}{l}0.0100 * * * \\
(0.000)\end{array}$ & $\begin{array}{l}0.00605^{* *} \\
(0.018)\end{array}$ & $\begin{array}{l}0.0133^{* * *} \\
(0.000)\end{array}$ & $\begin{array}{l}0.0106 * * * \\
(0.000)\end{array}$ \\
\hline age_18 & $\begin{array}{l}0.0752 * * * \\
(0.003)\end{array}$ & $\begin{array}{l}0.0531^{* *} \\
(0.016)\end{array}$ & $\begin{array}{l}-0.0174 \\
(0.529)\end{array}$ & $\begin{array}{r}0.0157 \\
(0.472)\end{array}$ & $\begin{array}{l}0.140 * * * \\
(0.000)\end{array}$ & $\begin{array}{c}0.131 * * * \\
(0.000)\end{array}$ & $\begin{array}{l}0.0638 * * \\
(0.013)\end{array}$ & $\begin{array}{c}0.109 * * * \\
(0.000)\end{array}$ \\
\hline age_19 & $\begin{array}{l}0.00533 \\
(0.833)\end{array}$ & $\begin{array}{r}0.0306 \\
(0.163)\end{array}$ & $\begin{array}{l}-0.0727 * * * \\
(0.008)\end{array}$ & $\begin{array}{l}-0.0236 \\
(0.278)\end{array}$ & $\begin{array}{l}0.0947^{* * *} \\
(0.001)\end{array}$ & $\begin{array}{l}0.114^{* * *} \\
(0.000)\end{array}$ & $\begin{array}{r}0.0334 \\
(0.187)\end{array}$ & $\begin{array}{l}0.0796 * * * \\
(0.000)\end{array}$ \\
\hline age_20 & $\begin{array}{l}-0.0442 * \\
(0.082)\end{array}$ & $\begin{array}{l}-0.0312 \\
(0.158)\end{array}$ & $\begin{array}{l}-0.111 * * * \\
(0.000)\end{array}$ & $\begin{array}{l}-0.0527^{* *} \\
(0.016)\end{array}$ & $\begin{array}{l}0.0618^{* *} \\
(0.031)\end{array}$ & $\begin{array}{l}0.0847 * * * \\
(0.000)\end{array}$ & $\begin{array}{l}-0.0160 \\
(0.529)\end{array}$ & $\begin{array}{l}0.0545^{* * *} \\
(0.009)\end{array}$ \\
\hline 2.income_quart & $\begin{array}{r}0.0196 \\
(0.272)\end{array}$ & $\begin{array}{l}0.0615^{* * * *} \\
(0.000)\end{array}$ & $\begin{array}{c}0.0312 * \\
(0.060)\end{array}$ & $\begin{array}{l}0.0450 * * * \\
(0.003)\end{array}$ & $\begin{array}{l}0.0565^{* * *} \\
(0.001)\end{array}$ & $\begin{array}{l}0.0658 * * * \\
(0.000)\end{array}$ & $\begin{array}{r}0.0150 \\
(0.340)\end{array}$ & $\begin{array}{r}0.0123 \\
(0.392)\end{array}$ \\
\hline 3.income_quart & $\begin{array}{l}0.0936 * * * \\
(0.000)\end{array}$ & $\begin{array}{l}0.0734^{* * * *} \\
(0.000)\end{array}$ & $\begin{array}{c}0.100 * * * \\
(0.000)\end{array}$ & $\begin{array}{c}0.105^{* * *} \\
(0.000)\end{array}$ & $\begin{array}{c}0.136^{* * *} \\
(0.000)\end{array}$ & $\begin{array}{l}0.125^{* * * *} \\
(0.000)\end{array}$ & $\begin{array}{l}0.0682^{* * *} \\
(0.000)\end{array}$ & $\begin{array}{l}0.0705^{* * *} \\
(0.000)\end{array}$ \\
\hline 4.income_quart & $\begin{array}{c}0.186^{* * *} \\
(0.000)\end{array}$ & $\begin{array}{c}0.162^{* * *} \\
(0.000)\end{array}$ & $\begin{array}{l}0.218^{* * * *} \\
(0.000)\end{array}$ & $\begin{array}{l}0.190 * * * \\
(0.000)\end{array}$ & $\begin{array}{l}0.221 * * * \\
(0.000)\end{array}$ & $\begin{array}{c}0.203^{* * * *} \\
(0.000)\end{array}$ & $\begin{array}{l}0.184^{* * *} \\
(0.000)\end{array}$ & $\begin{array}{c}0.145^{* * *} \\
(0.000)\end{array}$ \\
\hline mom_edu & $\begin{array}{l}0.0898 * * * \\
(0.000)\end{array}$ & $\begin{array}{l}0.0975^{* * * *} \\
(0.000)\end{array}$ & $\begin{array}{l}0.0771 * * * \\
(0.000)\end{array}$ & $\begin{array}{l}0.0722 * * * \\
(0.000)\end{array}$ & $\begin{array}{l}0.0726 * * * \\
(0.000)\end{array}$ & $\begin{array}{l}0.0607 * * * \\
(0.000)\end{array}$ & $\begin{array}{l}0.0647^{* * *} \\
(0.000)\end{array}$ & $\begin{array}{l}0.0587^{* * *} \\
(0.000)\end{array}$ \\
\hline nsibs & $\begin{array}{l}-0.0103 * * * \\
(0.005)\end{array}$ & $\begin{array}{c}-0.00982 * * * \\
(0.005)\end{array}$ & $\begin{array}{r}-0.00225 \\
(0.525)\end{array}$ & $\begin{array}{l}0.00310 \\
(0.338)\end{array}$ & $\begin{array}{r}0.000857 \\
(0.828)\end{array}$ & $\begin{array}{r}0.000416 \\
(0.905)\end{array}$ & $\begin{array}{l}0.00491 \\
(0.208)\end{array}$ & $\begin{array}{r}-0.00517 \\
(0.127)\end{array}$ \\
\hline black & $\begin{array}{l}-0.0754 * * * \\
(0.000)\end{array}$ & $\begin{array}{l}-0.0489 * * * \\
(0.001)\end{array}$ & $\begin{array}{l}-0.0451 * * * \\
(0.001)\end{array}$ & $\begin{array}{l}-0.0513^{* * *} \\
(0.000)\end{array}$ & $\begin{array}{r}-0.00839 \\
(0.601)\end{array}$ & $\begin{array}{l}-0.0340 * * * \\
(0.009)\end{array}$ & $\begin{array}{l}-0.0140 \\
(0.349)\end{array}$ & $\begin{array}{l}-0.0204 \\
(0.124)\end{array}$ \\
\hline hispanic & $\begin{array}{r}0.0315 \\
(0.120)\end{array}$ & $\begin{array}{r}0.0159 \\
(0.383)\end{array}$ & $\begin{array}{c}0.0297 * \\
(0.064)\end{array}$ & $\begin{array}{l}0.0372 * * * \\
(0.008)\end{array}$ & $\begin{array}{l}0.00313 \\
(0.827)\end{array}$ & $\begin{array}{l}0.00204 \\
(0.873)\end{array}$ & $\begin{array}{l}0.0768 * * * \\
(0.000)\end{array}$ & $\begin{array}{l}0.0570 * * * \\
(0.000)\end{array}$ \\
\hline others & $\begin{array}{l}0.0762 * * * \\
(0.002)\end{array}$ & $\begin{array}{l}0.0969 * * * \\
(0.000)\end{array}$ & $\begin{array}{l}0.0793 * * * \\
(0.000)\end{array}$ & $\begin{array}{l}0.0638 * * * \\
(0.001)\end{array}$ & $\begin{array}{l}0.0950 * * * \\
(0.000)\end{array}$ & $\begin{array}{r}-0.00113 \\
(0.944)\end{array}$ & $\begin{array}{l}0.0949 * * * \\
(0.000)\end{array}$ & $\begin{array}{r}0.0193 \\
(0.188)\end{array}$ \\
\hline N & 10626 & 10842 & 12492 & 12855 & 11010 & 11102 & 11109 & 10895 \\
\hline
\end{tabular}

p-values in parentheses

Source: IPUMS CPS

Including samples who were age 17-20 years old, graduated high school, and a child related to the head of a household.

Estimated by Probit and average marginal effect (AME) are reported.

State UE Effect on College Enrollment by Gender

$* \mathrm{p}<0.10, * * \mathrm{p}<0.05, * * * \mathrm{p}<0.010$ 
Table 5 Effect of State Unemployment Rate on College Enrollment Probability Among Race/Ethnicity Groups

\begin{tabular}{|c|c|c|c|c|c|c|c|c|c|}
\hline \multicolumn{5}{|l|}{ 1984-1989 } & \multicolumn{5}{|l|}{ 1990-1999 } \\
\hline & (1) & (2) & (3) & (4) & & (1) & (2) & (3) & (4) \\
\hline & White & Black & Hispanic & Others & & White & Black & Hispanic & Others \\
\hline UE_state & $\begin{array}{c}-0.00310^{*} \\
(0.063)\end{array}$ & $\begin{array}{r}-0.000605 \\
(0.897)\end{array}$ & $\begin{array}{l}-0.0147^{*} \\
(0.090)\end{array}$ & $\begin{array}{l}-0.0145 \\
(0.119)\end{array}$ & UE_state & $\begin{array}{r}-0.00160 \\
(0.406)\end{array}$ & $\begin{array}{r}-0.000437 \\
(0.942)\end{array}$ & $\begin{array}{l}0.0237 * * * \\
(0.001)\end{array}$ & $\begin{array}{l}0.0215^{* * *} \\
(0.001)\end{array}$ \\
\hline age_18 & $\begin{array}{l}0.0772 * * * \\
(0.000)\end{array}$ & $\begin{array}{r}0.0194 \\
(0.688)\end{array}$ & $\begin{array}{r}0.0137 \\
(0.856)\end{array}$ & $\begin{array}{l}-0.0188 \\
(0.815)\end{array}$ & age_18 & $\begin{array}{l}0.00777 \\
(0.705)\end{array}$ & $\begin{array}{l}-0.0374 \\
(0.447)\end{array}$ & $\begin{array}{r}-0.00117 \\
(0.984)\end{array}$ & $\begin{array}{r}0.0170 \\
(0.782)\end{array}$ \\
\hline age_19 & $\begin{array}{r}0.0293 \\
(0.116)\end{array}$ & $\begin{array}{l}-0.0327 \\
(0.497)\end{array}$ & $\begin{array}{l}-0.0150 \\
(0.842)\end{array}$ & $\begin{array}{l}-0.0542 \\
(0.497)\end{array}$ & age_19 & $\begin{array}{l}-0.0426 * * \\
(0.037)\end{array}$ & $\begin{array}{l}-0.0555 \\
(0.254)\end{array}$ & $\begin{array}{l}-0.0616 \\
(0.294)\end{array}$ & $\begin{array}{l}-0.0166 \\
(0.784)\end{array}$ \\
\hline age_20 & $\begin{array}{l}-0.0308 \\
(0.101)\end{array}$ & $\begin{array}{l}-0.0569 \\
(0.237)\end{array}$ & $\begin{array}{l}-0.0662 \\
(0.382)\end{array}$ & $\begin{array}{r}-0.114 \\
(0.153)\end{array}$ & age_20 & $\begin{array}{l}-0.0725 * * * \\
(0.000)\end{array}$ & $\begin{array}{l}-0.129 * * * \\
(0.008)\end{array}$ & $\begin{array}{l}-0.0720 \\
(0.222)\end{array}$ & $\begin{array}{l}-0.0665 \\
(0.274)\end{array}$ \\
\hline 2. income_quart & $\begin{array}{l}0.042 \theta^{* * *} \\
(0.007)\end{array}$ & $\begin{array}{l}0.0971^{* * *} \\
(0.000)\end{array}$ & $\begin{array}{l}-0.0221 \\
(0.544)\end{array}$ & $\begin{array}{c}0.110^{*} \\
(0.055)\end{array}$ & _Iincome_qu_2 & $\begin{array}{l}0.0357^{* * *} \\
(0.007)\end{array}$ & $\begin{array}{l}0.0669 * * * \\
(0.005)\end{array}$ & $\begin{array}{l}0.0507 * \\
(0.066)\end{array}$ & $\begin{array}{l}0.00545 \\
(0.881)\end{array}$ \\
\hline 3. income_quart & $\begin{array}{l}0.0937 * * * \\
(0.000)\end{array}$ & $\begin{array}{l}0.0741^{* * *} \\
(0.007)\end{array}$ & $\begin{array}{r}0.0564 \\
(0.136)\end{array}$ & $\begin{array}{l}0.149 * * * \\
(0.009)\end{array}$ & _Iincome_qu_3 & $\begin{array}{l}0.0971 * * * \\
(0.000)\end{array}$ & $\begin{array}{l}0.154^{* * *} \\
(0.000)\end{array}$ & $\begin{array}{l}0.122^{* * *} \\
(0.000)\end{array}$ & $\begin{array}{l}0.00804 \\
(0.819)\end{array}$ \\
\hline 4. income_quart & $\begin{array}{l}0.183^{* * *} \\
(0.000)\end{array}$ & $\begin{array}{l}0.165^{* * *} \\
(0.000)\end{array}$ & $\begin{array}{l}0.0789 * \\
(0.093)\end{array}$ & $\begin{array}{l}0.185^{* * *} \\
(0.001)\end{array}$ & _Iincome_qu_4 & $\begin{array}{c}0.197^{* * *} \\
(0.000)\end{array}$ & $\begin{array}{l}0.251^{* * *} \\
(0.000)\end{array}$ & $\begin{array}{l}0.187^{* * *} \\
(0.000)\end{array}$ & $\begin{array}{c}0.114^{* * *} \\
(0.002)\end{array}$ \\
\hline mom_edu & $\begin{array}{l}0.100 * * * \\
(0.000)\end{array}$ & $\begin{array}{l}0.0818^{* * *} \\
(0.000)\end{array}$ & $\begin{array}{l}0.0694 * * * \\
(0.000)\end{array}$ & $\begin{array}{l}0.0486^{* * *} \\
(0.000)\end{array}$ & mom_edu & $\begin{array}{l}0.0824 * * * \\
(0.000)\end{array}$ & $\begin{array}{l}0.0726^{* * *} \\
(0.000)\end{array}$ & $\begin{array}{l}0.0380 * * * \\
(0.000)\end{array}$ & $\begin{array}{l}0.0498^{* * *} \\
(0.000)\end{array}$ \\
\hline nsibs & $\begin{array}{c}-0.00972 * * * \\
(0.001)\end{array}$ & $\begin{array}{l}-0.0238^{* * *} \\
(0.001)\end{array}$ & $\begin{array}{c}-0.0000826 \\
(0.993)\end{array}$ & $\begin{array}{l}-0.0231^{*} \\
(0.062)\end{array}$ & nsibs & $\begin{array}{r}0.000125 \\
(0.965)\end{array}$ & $\begin{array}{l}-0.0110 \\
(0.136)\end{array}$ & $\begin{array}{r}-0.00197 \\
(0.801)\end{array}$ & $\begin{array}{r}-0.00732 \\
(0.414)\end{array}$ \\
\hline female & $\begin{array}{l}0.0472 * * * \\
(0.000)\end{array}$ & $\begin{array}{l}0.0775 * * * \\
(0.000)\end{array}$ & $\begin{array}{r}0.0299 \\
(0.276)\end{array}$ & $\begin{array}{l}0.0763^{* *} \\
(0.022)\end{array}$ & female & $\begin{array}{l}0.0872^{* * *} \\
(0.000)\end{array}$ & $\begin{array}{l}0.0876^{* * *} \\
(0.000)\end{array}$ & $\begin{array}{l}0.110^{* * *} \\
(0.000)\end{array}$ & $\begin{array}{l}0.0695^{* * *} \\
(0.002)\end{array}$ \\
\hline $\mathrm{N}$ & 17163 & 2334 & 1252 & 719 & $\mathrm{~N}$ & 19371 & 2643 & 1987 & 1344 \\
\hline \multicolumn{5}{|l|}{ 2000-2009 } & \multicolumn{5}{|l|}{$2010-2018$} \\
\hline & $\begin{array}{r}(1) \\
\text { White }\end{array}$ & $\begin{array}{r}(2) \\
\text { Black }\end{array}$ & $\begin{array}{r}(3) \\
\text { Hispanic }\end{array}$ & $\begin{array}{r}(4) \\
\text { Others }\end{array}$ & & $\begin{array}{r}(1) \\
\text { White }\end{array}$ & $\begin{array}{r}(2) \\
\text { Black }\end{array}$ & $\begin{array}{r}(3) \\
\text { Hispanic }\end{array}$ & $\begin{array}{r}(4) \\
\text { Others }\end{array}$ \\
\hline UE_state & $\begin{array}{l}0.00736^{* * *} \\
(0.001)\end{array}$ & $\begin{array}{r}0.0104 \\
(0.117)\end{array}$ & $\begin{array}{l}0.00601 \\
(0.298)\end{array}$ & $\begin{array}{l}0.0117 * \\
(0.081)\end{array}$ & UE_state & $\begin{array}{l}0.0128^{* * *} \\
(0.000)\end{array}$ & $\begin{array}{l}0.0110^{* *} \\
(0.014)\end{array}$ & $\begin{array}{l}0.00765^{* *} \\
(0.010)\end{array}$ & $\begin{array}{l}0.0185^{* * *} \\
(0.000)\end{array}$ \\
\hline age_18 & $\begin{array}{l}0.168^{* * *} \\
(0.000)\end{array}$ & $\begin{array}{l}0.0993 * \\
(0.066)\end{array}$ & $\begin{array}{r}0.0455 \\
(0.391)\end{array}$ & $\begin{array}{c}0.124 * * \\
(0.024)\end{array}$ & age_18 & $\begin{array}{l}0.0945^{* * *} \\
(0.000)\end{array}$ & $\begin{array}{l}0.119 * * \\
(0.033)\end{array}$ & $\begin{array}{l}0.0623 * \\
(0.098)\end{array}$ & $\begin{array}{r}0.0722 \\
(0.107)\end{array}$ \\
\hline age_19 & $\begin{array}{l}0.142^{* * *} \\
(0.000)\end{array}$ & $\begin{array}{r}0.0713 \\
(0.183)\end{array}$ & $\begin{array}{l}-0.0191 \\
(0.717)\end{array}$ & $\begin{array}{l}0.0907 * \\
(0.096)\end{array}$ & age_19 & $\begin{array}{l}0.0645^{* * *} \\
(0.002)\end{array}$ & $\begin{array}{l}0.0953^{*} \\
(0.084)\end{array}$ & $\begin{array}{r}0.0294 \\
(0.431)\end{array}$ & $\begin{array}{r}0.0357 \\
(0.421)\end{array}$ \\
\hline age_20 & $\begin{array}{l}0.110^{* * *} \\
(0.000)\end{array}$ & $\begin{array}{r}0.0547 \\
(0.311)\end{array}$ & $\begin{array}{l}-0.0672 \\
(0.203)\end{array}$ & $\begin{array}{r}0.0698 \\
(0.205)\end{array}$ & age_20 & $\begin{array}{r}0.0277 \\
(0.193)\end{array}$ & $\begin{array}{r}0.0739 \\
(0.181)\end{array}$ & $\begin{array}{l}-0.0336 \\
(0.369)\end{array}$ & $\begin{array}{r}0.0238 \\
(0.592)\end{array}$ \\
\hline _Iincome_qu_2 & $\begin{array}{l}0.0669 * * * \\
(0.000)\end{array}$ & $\begin{array}{r}0.0120 \\
(0.649)\end{array}$ & $\begin{array}{l}0.0792^{* * *} \\
(0.001)\end{array}$ & $\begin{array}{l}0.0651 * \\
(0.053)\end{array}$ & _Iincome_qu_2 & $\begin{array}{r}0.0200 \\
(0.163)\end{array}$ & $\begin{array}{r}-0.00103 \\
(0.968)\end{array}$ & $\begin{array}{r}0.0221 \\
(0.244)\end{array}$ & $\begin{array}{r}0.0367 \\
(0.218)\end{array}$ \\
\hline _Iincome_qu_3 & $\begin{array}{l}0.129 * * * \\
(0.000)\end{array}$ & $\begin{array}{l}0.0927^{* * *} \\
(0.001)\end{array}$ & $\begin{array}{l}0.139 * * * \\
(0.000)\end{array}$ & $\begin{array}{l}0.138 * * * \\
(0.000)\end{array}$ & _Iincome_qu_3 & $\begin{array}{l}0.0837 * * * \\
(0.000)\end{array}$ & $\begin{array}{l}0.0847 * * * \\
(0.002)\end{array}$ & $\begin{array}{l}0.0461 * * \\
(0.023)\end{array}$ & $\begin{array}{l}0.0492 * \\
(0.088)\end{array}$ \\
\hline _Iincome_qu_4 & $\begin{array}{l}0.206 * * * \\
(0.000)\end{array}$ & $\begin{array}{l}0.192^{* * *} \\
(0.000)\end{array}$ & $\begin{array}{l}0.223^{* * *} \\
(0.000)\end{array}$ & $\begin{array}{l}0.225^{* * *} \\
(0.000)\end{array}$ & _Iincome_qu_4 & $\begin{array}{l}0.179 * * * \\
(0.000)\end{array}$ & $\begin{array}{l}0.159 * * * \\
(0.000)\end{array}$ & $\begin{array}{l}0.124^{* * *} \\
(0.000)\end{array}$ & $\begin{array}{l}0.120^{* * *} \\
(0.000)\end{array}$ \\
\hline mom_edu & $\begin{array}{l}0.0745^{* * *} \\
(0.000)\end{array}$ & $\begin{array}{l}0.0759 * * * \\
(0.000)\end{array}$ & $\begin{array}{l}0.0434 * * * \\
(0.000)\end{array}$ & $\begin{array}{l}0.0366 * * * \\
(0.000)\end{array}$ & mom_edu & $\begin{array}{l}0.0759 * * * \\
(0.000)\end{array}$ & $\begin{array}{l}0.0497 * * * \\
(0.000)\end{array}$ & $\begin{array}{l}0.0419 * * * \\
(0.000)\end{array}$ & $\begin{array}{l}0.0468^{* * *} \\
(0.000)\end{array}$ \\
\hline nsibs & $\begin{array}{l}0.00366 \\
(0.241)\end{array}$ & $\begin{array}{r}-0.00942 \\
(0.264)\end{array}$ & $\begin{array}{l}-0.0121 \\
(0.149)\end{array}$ & $\begin{array}{l}-0.0117 \\
(0.200)\end{array}$ & nsibs & $\begin{array}{r}-0.000603 \\
(0.858)\end{array}$ & $\begin{array}{l}0.00136 \\
(0.863)\end{array}$ & $\begin{array}{l}-0.0106 * \\
(0.094)\end{array}$ & $\begin{array}{r}-0.00612 \\
(0.393)\end{array}$ \\
\hline female & $\begin{array}{l}0.118^{* * *} \\
(0.000)\end{array}$ & $\begin{array}{l}0.0981 * * * \\
(0.000)\end{array}$ & $\begin{array}{c}0.127^{* * *} \\
(0.000)\end{array}$ & $\begin{array}{r}0.0278 \\
(0.213)\end{array}$ & female & $\begin{array}{c}0.115^{* * *} \\
(0.000)\end{array}$ & $\begin{array}{c}0.116^{* * *} \\
(0.000)\end{array}$ & $\begin{array}{l}0.106 * * * \\
(0.000)\end{array}$ & $\begin{array}{l}0.0454 * * \\
(0.018)\end{array}$ \\
\hline $\mathrm{N}$ & 16033 & 2072 & 2530 & 1476 & $\mathrm{~N}$ & 13633 & 2299 & 4051 & 2021 \\
\hline
\end{tabular}




\section{Table 6 Summary Statistics of 18-Year-Old High School Graduates}

\begin{tabular}{|c|c|c|c|c|c|}
\hline Variable & Obs & Mean & Std. Dev. & Min & Max \\
\hline Enroll college & 6837 & .64 & .48 & 0 & 1 \\
\hline UE state & 6837 & 6.52 & 2.08 & 2.2 & 15.2 \\
\hline income quart & 6837 & 2.91 & 1.02 & 1 & 4 \\
\hline mom edu & 6837 & 3.66 & 1.4 & 0 & 6 \\
\hline nsibs & 6837 & 1.45 & 1.25 & 0 & 9 \\
\hline female & 6837 & .52 & .5 & 0 & 1 \\
\hline white & 6837 & .81 & .4 & 0 & 1 \\
\hline black & 6837 & .1 & .3 & 0 & 1 \\
\hline hispanic & 6837 & .06 & .24 & 0 & 1 \\
\hline others & 6837 & .03 & .18 & 0 & 1 \\
\hline
\end{tabular}

\begin{tabular}{lrrrrr}
$\mathbf{1 9 9 0 - 1 9 9 9}$ & Obs & Mean & Std. Dev. & Min & Max \\
\hline Variable & 7778 & .72 & .45 & 0 & 1 \\
\hline Enroll college & 7778 & 5.77 & 1.62 & .4 & 11.5 \\
UE state & 7778 & 2.96 & .99 & 1 & 4 \\
income quart & 7778 & 3.97 & 1.41 & 0 & 6 \\
mom edu & 7778 & 1.31 & 1.15 & .5 & 9 \\
nsibs & 7778 & .53 & .42 & 0 & 1 \\
female & 7778 & .77 & .3 & 0 & 1 \\
white & 7778 & .1 & .26 & 0 & 1 \\
black & 7778 & .08 & .22 & 0 & 1 \\
hispanic & 7778 & & & 0 & 1 \\
others & & & & & 0 \\
\hline
\end{tabular}

\begin{tabular}{lrrrrr}
$\mathbf{2 0 0 0 - 2 0 0 9}$ & Obs & Mean & Std. Dev. & Min & Max \\
\hline Variable & 6799 & .72 & .45 & 0 & 1 \\
\hline Enroll college & 6799 & 5.21 & 1.59 & 2.4 & 12.9 \\
UE state & 6799 & 2.86 & 1.02 & 1 & 4 \\
income quart & 6799 & 4.24 & 1.39 & 0 & 6 \\
mom edu & 6799 & 1.29 & 1.11 & .5 & 9 \\
nsibs & 6799 & .52 & .44 & 0 & 1 \\
female & 6799 & .73 & .29 & 0 & 1 \\
white & 6799 & .09 & .31 & 0 & 1 \\
black & 6799 & .11 & .07 & 0 & 1 \\
hispanic & 6799 & & & 0 & 1 \\
others & & & & 0 & 0 \\
\hline
\end{tabular}

\begin{tabular}{|c|c|c|c|c|c|}
\hline Variable & Obs & Mean & Std. Dev. & Min & Max \\
\hline Enroll college & 6472 & .72 & .45 & 0 & 1 \\
\hline UE state & 6472 & 6.64 & 2.36 & 2.3 & 13.5 \\
\hline income quart & 6472 & 2.77 & 1.01 & 1 & 4 \\
\hline mom edu & 6472 & 4.38 & 1.46 & 0 & 6 \\
\hline nsibs & 6472 & 1.34 & 1.15 & 0 & 9 \\
\hline female & 6472 & .51 & .5 & 0 & 1 \\
\hline white & 6472 & .62 & .48 & 0 & 1 \\
\hline black & 6472 & .1 & .3 & 0 & 1 \\
\hline hispanic & 6472 & .18 & .39 & 0 & 1 \\
\hline others & 6472 & .09 & .29 & 0 & 1 \\
\hline
\end{tabular}

Source: IPUMS CPS; Bureau of Labor Statistics

Including samples who were age 18 years old, graduated high school, and a child related to the head of the surveyed household. 
Table 7 Effect of State Unemployment Rate on College Enrollment Probability of 18-YearOld High School Graduates

\begin{tabular}{|c|c|c|c|c|}
\hline & $\begin{array}{r}(1) \\
84-89\end{array}$ & $\begin{array}{r}(2) \\
90-99\end{array}$ & $\begin{array}{r}(3) \\
00-09\end{array}$ & $\begin{array}{r}(4) \\
10-18\end{array}$ \\
\hline UE_state & $\begin{array}{r}-0.00105 \\
(0.689)\end{array}$ & $\begin{array}{l}0.00380 \\
(0.208)\end{array}$ & $\begin{array}{l}0.00711 * * \\
(0.029)\end{array}$ & $\begin{array}{l}0.0116^{* * *} \\
(0.000)\end{array}$ \\
\hline _Iincome_qu_2 & $\begin{array}{l}0.0475^{* *} \\
(0.013)\end{array}$ & $\begin{array}{r}0.0172 \\
(0.317)\end{array}$ & $\begin{array}{l}0.0535^{* * * *} \\
(0.001)\end{array}$ & $\begin{array}{r}-0.00290 \\
(0.865)\end{array}$ \\
\hline _Iincome_qu_3 & $\begin{array}{l}0.0989 * * * \\
(0.000)\end{array}$ & $\begin{array}{l}0.0849 * * * \\
(0.000)\end{array}$ & $\begin{array}{c}0.124^{* * *} \\
(0.000)\end{array}$ & $\begin{array}{l}0.0556^{* * *} \\
(0.001)\end{array}$ \\
\hline _Iincome_qu_4 & $\begin{array}{c}0.186^{* * *} \\
(0.000)\end{array}$ & $\begin{array}{c}0.174 * * * \\
(0.000)\end{array}$ & $\begin{array}{l}0.220^{* * *} \\
(0.000)\end{array}$ & $\begin{array}{l}0.154^{* * *} \\
(0.000)\end{array}$ \\
\hline mom_edu & $\begin{array}{l}0.0892 * * * \\
(0.000)\end{array}$ & $\begin{array}{l}0.0664^{* * *} \\
(0.000)\end{array}$ & $\begin{array}{l}0.0627 * * * \\
(0.000)\end{array}$ & $\begin{array}{l}0.0577^{* * *} \\
(0.000)\end{array}$ \\
\hline nsibs & $\begin{array}{l}-0.0157^{* * *} \\
(0.000)\end{array}$ & $\begin{array}{r}0.000552 \\
(0.895)\end{array}$ & $\begin{array}{r}-0.00559 \\
(0.223)\end{array}$ & $\begin{array}{c}-0.00872 * \\
(0.057)\end{array}$ \\
\hline female & $\begin{array}{l}0.0249 * * \\
(0.022)\end{array}$ & $\begin{array}{l}0.0762^{* * *} \\
(0.000)\end{array}$ & $\begin{array}{l}0.0915^{* * *} \\
(0.000)\end{array}$ & $\begin{array}{l}0.100 * * * \\
(0.000)\end{array}$ \\
\hline black & $\begin{array}{l}-0.0635^{* * *} \\
(0.001)\end{array}$ & $\begin{array}{l}-0.0622^{* * *} \\
(0.000)\end{array}$ & $\begin{array}{l}-0.0233 \\
(0.188)\end{array}$ & $\begin{array}{l}-0.0273 \\
(0.131)\end{array}$ \\
\hline hispanic & $\begin{array}{l}0.00589 \\
(0.798)\end{array}$ & $\begin{array}{r}0.0143 \\
(0.439)\end{array}$ & $\begin{array}{r}0.0275 \\
(0.102)\end{array}$ & $\begin{array}{l}0.0696^{* * *} \\
(0.000)\end{array}$ \\
\hline others & $\begin{array}{l}0.0661 * * \\
(0.039)\end{array}$ & $\begin{array}{l}0.0642^{* * *} \\
(0.006)\end{array}$ & $\begin{array}{l}0.0458^{* *} \\
(0.030)\end{array}$ & $\begin{array}{l}0.0521^{* * *} \\
(0.007)\end{array}$ \\
\hline $\mathrm{N}$ & 6837 & 7778 & 6799 & 6472 \\
\hline
\end{tabular}

p-values in parentheses

Source: IPUMS CPS

Including samples who were age 18 years old, graduated high school, and a child related to the head of a household

Estimated by Probit and AME are reported

Effect of State UE on College Enrollment of 18 Aged HSGs

$* p<0.10, * * p<0.05, * * * p<0.010$ 
Table $8 \quad$ Summary Statistics the NLSY97 vs. the CPS

The NLSY97 17-20-Year-Old High School Graduates

\begin{tabular}{|c|c|c|c|c|c|}
\hline Variable & Obs & Mean & Std. Dev. & Min & $\operatorname{Max}$ \\
\hline Enroll college & 9234 & .54 & .5 & 0 & 1 \\
\hline YEAR & 9234 & 2001.2 & 1.63 & 1997 & 2005 \\
\hline UE & 9234 & 5.13 & 1.88 & 1 & 18.8 \\
\hline age & 9234 & 19.12 & .81 & 17 & 20 \\
\hline age 17 & 9234 & .01 & .11 & 0 & 1 \\
\hline age 18 & 9234 & .24 & .43 & 0 & 1 \\
\hline age 19 & 9234 & .37 & .48 & 0 & 1 \\
\hline age 20 & 9234 & .38 & .49 & 0 & 1 \\
\hline income quart & 9234 & 2.86 & 1.05 & 1 & 4 \\
\hline mom edu & 9234 & 4.13 & 1.48 & 1 & 6 \\
\hline HHunder18 1997 & 9234 & 2.28 & 1.11 & 0 & 8 \\
\hline female & 9234 & .53 & .5 & 0 & 1 \\
\hline white & 9234 & .75 & .43 & 0 & 1 \\
\hline black & 9234 & .13 & .34 & 0 & 1 \\
\hline hispanic & 9234 & .12 & .32 & 0 & 1 \\
\hline
\end{tabular}

Source: NLSY97

Mixed race and minority oversamples are excluded.

Pulled from 1997 to 2005.

The CPS 17-20-Year-Old High School Graduates 1997-2005

\begin{tabular}{|c|c|c|c|c|c|}
\hline Variable & Obs & Mean & Std. Dev. & Min & Max \\
\hline Enroll college & 18894 & .68 & .47 & 0 & 1 \\
\hline year & 18894 & 2001.04 & 2.57 & 1997 & 2005 \\
\hline UE state & 18894 & 4.86 & 1.16 & 2.4 & 8.8 \\
\hline age & 18894 & 18.94 & .85 & 17 & 20 \\
\hline age 17 & 18894 & .03 & .16 & 0 & 1 \\
\hline age 18 & 18894 & .31 & .46 & 0 & 1 \\
\hline age 19 & 18894 & .36 & .48 & 0 & 1 \\
\hline age 20 & 18894 & .31 & .46 & 0 & 1 \\
\hline income quart & 18894 & 2.94 & 1.02 & 1 & 4 \\
\hline mom edu & 18894 & 4.12 & 1.4 & 0 & 6 \\
\hline nsibs & 18894 & 1.24 & 1.11 & 0 & 9 \\
\hline female & 18894 & .51 & .5 & 0 & 1 \\
\hline white & 18894 & .8 & .4 & 0 & 1 \\
\hline black & 18894 & .1 & .3 & 0 & 1 \\
\hline hispanic & 18894 & .1 & .31 & 0 & 1 \\
\hline
\end{tabular}

Source: IPUMS CPS

Other/mixed race and samples who are not related to the head of the surveyed household are excluded. 
Table 9 Effect of State Unemployment Rate on College Enrollment Probability of the 19972005 CPS

\begin{tabular}{|c|c|c|c|c|c|c|}
\hline & $\begin{array}{c}(1) \\
\text { Main }\end{array}$ & $\begin{array}{r}(2) \\
\text { Males }\end{array}$ & $\begin{array}{r}(3) \\
\text { Females }\end{array}$ & $\begin{array}{r}(4) \\
\text { White }\end{array}$ & $\begin{array}{r}(5) \\
\text { Black }\end{array}$ & $\begin{array}{r}(6) \\
\text { Hispanic }\end{array}$ \\
\hline UE_state & $\begin{array}{l}0.00982^{* * *} \\
(0.000)\end{array}$ & $\begin{array}{l}0.0100^{* *} \\
(0.015)\end{array}$ & $\begin{array}{l}0.00959 * * \\
(0.012)\end{array}$ & $\begin{array}{l}0.00856 * * * \\
(0.005)\end{array}$ & $\begin{array}{l}0.00136 \\
(0.882)\end{array}$ & $\begin{array}{l}0.0306^{* * *} \\
(0.005)\end{array}$ \\
\hline age_18 & $\begin{array}{c}0.134^{* * *} \\
(0.000)\end{array}$ & $\begin{array}{c}0.134^{* * *} \\
(0.000)\end{array}$ & $\begin{array}{c}0.131 * * * \\
(0.000)\end{array}$ & $\begin{array}{c}0.158^{* * *} \\
(0.000)\end{array}$ & $\begin{array}{r}0.0375 \\
(0.525)\end{array}$ & $\begin{array}{r}0.0894 \\
(0.154)\end{array}$ \\
\hline age_19 & $\begin{array}{l}0.0929 * * * \\
(0.000)\end{array}$ & $\begin{array}{l}0.0939 * * * \\
(0.004)\end{array}$ & $\begin{array}{l}0.0897 * * * \\
(0.000)\end{array}$ & $\begin{array}{c}0.122^{* * *} \\
(0.000)\end{array}$ & $\begin{array}{l}0.00535 \\
(0.927)\end{array}$ & $\begin{array}{r}-0.000471 \\
(0.994)\end{array}$ \\
\hline age_20 & $\begin{array}{l}0.0675^{* * *} \\
(0.001)\end{array}$ & $\begin{array}{c}0.0642 * \\
(0.051)\end{array}$ & $\begin{array}{l}0.0684 * * * \\
(0.005)\end{array}$ & $\begin{array}{l}0.0928 * * * \\
(0.000)\end{array}$ & $\begin{array}{r}-0.00385 \\
(0.948)\end{array}$ & $\begin{array}{l}-0.0167 \\
(0.790)\end{array}$ \\
\hline _Iincome_qu_2 & $\begin{array}{l}0.0613^{* * *} \\
(0.000)\end{array}$ & $\begin{array}{l}0.0508^{* * *} \\
(0.004)\end{array}$ & $\begin{array}{l}0.0692^{* * *} \\
(0.000)\end{array}$ & $\begin{array}{l}0.0672^{* * *} \\
(0.000)\end{array}$ & $\begin{array}{c}0.0520^{*} \\
(0.059)\end{array}$ & $\begin{array}{l}0.0855^{* * *} \\
(0.002)\end{array}$ \\
\hline _Iincome_qu_3 & $\begin{array}{c}0.113^{* * *} \\
(0.000)\end{array}$ & $\begin{array}{c}0.122^{* * *} \\
(0.000)\end{array}$ & $\begin{array}{c}0.104 * * * \\
(0.000)\end{array}$ & $\begin{array}{c}0.122^{* * *} \\
(0.000)\end{array}$ & $\begin{array}{c}0.129 * * * \\
(0.000)\end{array}$ & $\begin{array}{l}0.105^{* * *} \\
(0.001)\end{array}$ \\
\hline _Iincome_qu_4 & $\begin{array}{c}0.198^{* * *} \\
(0.000)\end{array}$ & $\begin{array}{c}0.216^{* * *} \\
(0.000)\end{array}$ & $\begin{array}{c}0.179 * * * \\
(0.000)\end{array}$ & $\begin{array}{c}0.201^{* * *} \\
(0.000)\end{array}$ & $\begin{array}{c}0.208^{* * *} \\
(0.000)\end{array}$ & $\begin{array}{l}0.204^{* * *} \\
(0.000)\end{array}$ \\
\hline mom_edu & $\begin{array}{l}0.0719 * * * \\
(0.000)\end{array}$ & $\begin{array}{l}0.0776^{* * *} \\
(0.000)\end{array}$ & $\begin{array}{l}0.0662^{* * *} \\
(0.000)\end{array}$ & $\begin{array}{l}0.0776^{* * *} \\
(0.000)\end{array}$ & $\begin{array}{l}0.0794 * * * \\
(0.000)\end{array}$ & $\begin{array}{l}0.0378 * * * \\
(0.000)\end{array}$ \\
\hline nsibs & $\begin{array}{l}0.00110 \\
(0.701)\end{array}$ & $\begin{array}{l}0.00177 \\
(0.683)\end{array}$ & $\begin{array}{r}0.000460 \\
(0.903)\end{array}$ & $\begin{array}{l}0.00104 \\
(0.747)\end{array}$ & $\begin{array}{r}-0.00296 \\
(0.737)\end{array}$ & $\begin{array}{r}-0.00889 \\
(0.324)\end{array}$ \\
\hline female & $\begin{array}{c}0.111^{* * *} \\
(0.000)\end{array}$ & $\begin{array}{l}0 \\
(.)\end{array}$ & $\begin{array}{l}0 \\
(.)\end{array}$ & $\begin{array}{c}0.111^{* * *} \\
(0.000)\end{array}$ & $\begin{array}{l}0.0836 * * * \\
(0.000)\end{array}$ & $\begin{array}{l}0.135^{* * *} \\
(0.000)\end{array}$ \\
\hline black & $\begin{array}{l}-0.0301 * * * \\
(0.005)\end{array}$ & $\begin{array}{r}-0.00691 \\
(0.682)\end{array}$ & $\begin{array}{l}-0.0473^{* * *} \\
(0.001)\end{array}$ & $\begin{array}{l}0 \\
(.)\end{array}$ & $\begin{array}{l}\theta \\
(.)\end{array}$ & $\begin{array}{l}0 \\
(.)\end{array}$ \\
\hline hispanic & $\begin{array}{l}0.00729 \\
(0.503)\end{array}$ & $\begin{array}{l}0.00558 \\
(0.735)\end{array}$ & $\begin{array}{l}0.00797 \\
(0.580)\end{array}$ & $\begin{array}{l}0 \\
(.)\end{array}$ & $\begin{array}{l}0 \\
(.)\end{array}$ & $\begin{array}{l}0 \\
(.)\end{array}$ \\
\hline $\mathrm{N}$ & 18894 & 9313 & 9581 & 15033 & 1887 & 1973 \\
\hline
\end{tabular}

p-values in parentheses

Source: IPUMS CPS

Including samples who were age 17-20 years old, graduated high school, and a child related to the head of the surveyed household. Other/mixed rece are excluded.

Estimated by Probit and AMEs are reported.

State UE Effect on College Enrollment of 17-20 Years Old High School Graduates

$* \mathrm{p}<0.10, * * \mathrm{p}<0.05, * * * \mathrm{p}<0.010$ 
Table 10 Two-way Frequencies of Institution Types and HSG Types

\begin{tabular}{r|rrr|r}
$\begin{array}{r}\text { year completed } \\
\text { high school }\end{array}$ & \multicolumn{4}{|c}{$\begin{array}{c}\text { enrolled in a 2-year or 4-year } \\
\text { college or university }\end{array}$} \\
\hline 2-year co & 4-year co & niu & Total \\
\hline $\begin{array}{r}\text { current year } \\
\text { some previous year }\end{array}$ & $\begin{array}{l}1,424 \\
2,117\end{array}$ & $\begin{array}{l}3,277 \\
6,022\end{array}$ & $\begin{array}{r}2,015 \\
4,039\end{array}$ & $\begin{array}{r}6,716 \\
12,178\end{array}$ \\
\hline Total & 3,541 & 9,299 & 6,054 & 18,894
\end{tabular}


Table 11 Effect of State UE on 2-year College vs. 4-year University Enrollment for the CPS 1997-2005

\begin{tabular}{|c|c|c|c|}
\hline & $\begin{array}{l}(1) \\
\text { All }\end{array}$ & $\begin{array}{r}(2) \\
\text { Current }\end{array}$ & $\begin{array}{r}\text { (3) } \\
\text { Previous }\end{array}$ \\
\hline \multicolumn{4}{|l|}{ 2_year_college } \\
\hline UE_state & $\begin{array}{l}0.135 * * * \\
(0.000)\end{array}$ & $\begin{array}{l}\theta .165 * * * \\
(\theta .000)\end{array}$ & $\begin{array}{l}0.120 * * * \\
(0.000)\end{array}$ \\
\hline age_18 & $\begin{array}{l}0.508^{* * * *} \\
(0.000)\end{array}$ & $\begin{array}{l}0.456 * * \\
(0.002)\end{array}$ & $\begin{array}{c}0.618^{*} \\
(0.02 \theta)\end{array}$ \\
\hline age_19 & $\begin{array}{c}0.266^{*} \\
(0.039)\end{array}$ & $\begin{array}{r}-0.00586 \\
(0.971)\end{array}$ & $\begin{array}{c}0.728^{* *} \\
(0.005)\end{array}$ \\
\hline age_20 & $\begin{array}{r}-0.118 \\
(0.366)\end{array}$ & $\begin{array}{r}-0.260 \\
(0.309)\end{array}$ & $\begin{array}{r}0.298 \\
(0.248)\end{array}$ \\
\hline _Iincome_qu_2 & $\begin{array}{l}0.344 * * * \\
(0.000)\end{array}$ & $\begin{array}{l}0.490 * * * \\
(0.000)\end{array}$ & $\begin{array}{c}0.242^{*} \\
(0.012)\end{array}$ \\
\hline _Iincome_qu_3 & $\begin{array}{l}0.528^{* * * *} \\
(0.000)\end{array}$ & $\begin{array}{l}0.656^{* * * *} \\
(0.000)\end{array}$ & $\begin{array}{l}0.435 * * * \\
(0.000)\end{array}$ \\
\hline _Iincome_qu_4 & $\begin{array}{l}0.780^{* * * *} \\
(0.000)\end{array}$ & $\begin{array}{l}0.955^{* * *} \\
(0.000)\end{array}$ & $\begin{array}{l}0.666 * * * \\
(0.000)\end{array}$ \\
\hline mom_edu & $\begin{array}{l}0.188^{* * * *} \\
(0.000)\end{array}$ & $\begin{array}{l}0.180^{* * *} \\
(0.000)\end{array}$ & $\begin{array}{l}0.194 * * * \\
(0.000)\end{array}$ \\
\hline nsibs & $\begin{array}{l}-0.0202 \\
(0.302)\end{array}$ & $\begin{array}{l}-0.0166 \\
(0.603)\end{array}$ & $\begin{array}{l}-0.0203 \\
(0.414)\end{array}$ \\
\hline female & $\begin{array}{l}0.447 * * * \\
(0.000)\end{array}$ & $\begin{array}{l}0.521 * * * \\
(0.000)\end{array}$ & $\begin{array}{l}0.399 * * * \\
(0.000)\end{array}$ \\
\hline black & $\begin{array}{l}-0.151 * \\
(0.041)\end{array}$ & $\begin{array}{r}-0.147 \\
(0.232)\end{array}$ & $\begin{array}{r}-0.144 \\
(0.121)\end{array}$ \\
\hline hispanic & $\begin{array}{l}0.246 * * * \\
(0.000)\end{array}$ & $\begin{array}{r}0.216 \\
(0.064)\end{array}$ & $\begin{array}{l}0.272 * * \\
(0.002)\end{array}$ \\
\hline $\begin{array}{l}\text { 4_year_college } \\
\text { UE_state }\end{array}$ & $\begin{array}{r}0.0141 \\
(0.368)\end{array}$ & $\begin{array}{l}0.0545 * \\
(0.045)\end{array}$ & $\begin{array}{r}-0.00729 \\
(0.705)\end{array}$ \\
\hline age_18 & $\begin{array}{l}0.799 * * * \\
(0.000)\end{array}$ & $\begin{array}{l}0.747 * * * \\
(0.000)\end{array}$ & $\begin{array}{l}0.889 * * * \\
(0.000)\end{array}$ \\
\hline age_19 & $\begin{array}{l}0.595 * * * \\
(0.000)\end{array}$ & $\begin{array}{r}0.184 \\
(0.201)\end{array}$ & $\begin{array}{l}1.156 * * * \\
(0.000)\end{array}$ \\
\hline age_20 & $\begin{array}{l}0.574 * * * \\
(0.000)\end{array}$ & $\begin{array}{l}-0.0557 \\
(0.803)\end{array}$ & $\begin{array}{l}1.073^{* * *} \\
(0.000)\end{array}$ \\
\hline _Iincome_qu_2 & $\begin{array}{l}0.303 * * * \\
(0.000)\end{array}$ & $\begin{array}{l}0.337 * * \\
(0.002)\end{array}$ & $\begin{array}{l}0.275 * * * \\
(0.001)\end{array}$ \\
\hline _Iincome_qu_3 & $\begin{array}{l}0.607 * * * \\
(0.000)\end{array}$ & $\begin{array}{l}0.663^{* * *} \\
(0.000)\end{array}$ & $\begin{array}{l}0.553^{* * *} \\
(0.000)\end{array}$ \\
\hline _Iincome_qu_4 & $\begin{array}{l}1.119 * * * \\
(0.000)\end{array}$ & $\begin{array}{l}1.235 * * * \\
(0.000)\end{array}$ & $\begin{array}{l}1.036 * * * \\
(0.000)\end{array}$ \\
\hline mom_edu & $\begin{array}{l}0.454 * * * \\
(0.000)\end{array}$ & $\begin{array}{l}0.446 * * * \\
(0.000)\end{array}$ & $\begin{array}{l}0.459 * * * \\
(0.000)\end{array}$ \\
\hline nsibs & $\begin{array}{r}0.0165 \\
(0.306)\end{array}$ & $\begin{array}{r}0.0162 \\
(0.557)\end{array}$ & $\begin{array}{r}0.0202 \\
(0.310)\end{array}$ \\
\hline female & $\begin{array}{l}0.638^{* * *} \\
(0.000)\end{array}$ & $\begin{array}{l}0.675^{* * *} \\
(0.000)\end{array}$ & $\begin{array}{l}0.609 * * * \\
(0.000)\end{array}$ \\
\hline black & $\begin{array}{l}-0.152 * \\
(0.012)\end{array}$ & $\begin{array}{r}-0.167 \\
(0.114)\end{array}$ & $\begin{array}{c}-0.128 \\
(0.081)\end{array}$ \\
\hline hispanic & $\begin{array}{l}-0.134 * \\
(0.036)\end{array}$ & $\begin{array}{r}-0.184 \\
(0.104)\end{array}$ & $\begin{array}{l}-0.0962 \\
(0.215)\end{array}$ \\
\hline $\begin{array}{l}\text { N } \\
\text { pseudo } R-s q\end{array}$ & $\begin{array}{l}18894 \\
0.077\end{array}$ & $\begin{array}{r}6716 \\
0.081\end{array}$ & $\begin{array}{l}12178 \\
0.076\end{array}$ \\
\hline
\end{tabular}

p-values in parentheses

Source: IPUMS CPS

Including samples who were age 17-20 years old, graduated high school,

and a child related to the head of hesurveyed household. Other/mixed rece are excluded.

Estimated by multinomial logistic regression.

Samples who do not enroll in a 2-year or 4-year college are the base group.

Effect of State UE on 2-year vs. 4-year College Enrollment of 17-20 Years old High School Graduates From Year 97-05

$* p<0.05, * * p<0.01, * * * p<0.001$ 


\section{Appendix}

Table A-1 Relationship to the Head of the Surveyed Household

1984-1989

\begin{tabular}{r|rrr} 
relationship to household head & Freq. & Percent & Cum. \\
\hline head/householder & 56 & 0.26 & 0.26 \\
child & 21,468 & 98.95 & 99.21 \\
sibling & 39 & 0.18 & 99.39 \\
other relatives, n.s & 48 & 0.22 & 99.61 \\
other nonrelatives & 84 & 0.39 & 100.00 \\
\hline Total & 21,695 & 100.00 &
\end{tabular}

1990-1999

\begin{tabular}{r|rrr} 
relationship to household head & Freq. & Percent & Cum. \\
\hline head/householder & 207 & 0.79 & 0.79 \\
child & 25,347 & 96.71 & 97.50 \\
sibling & 143 & 0.55 & 98.05 \\
grandchild & 161 & 0.61 & 98.66 \\
other relatives, n.s & 195 & 0.74 & 99.41 \\
housemate/roomate & 16 & 0.06 & 99.47 \\
roomer/boarder/lodger & 1 & 0.00 & 99.47 \\
other nonrelatives & 138 & 0.53 & 100.00 \\
\hline Total & 26,208 & 100.00 &
\end{tabular}

2000-2009

\begin{tabular}{r|rrr} 
relationship to household head & Freq. & Percent & Cum. \\
\hline head/householder & 625 & 2.65 & 2.65 \\
child & 22,112 & 93.60 & 96.25 \\
sibling & 359 & 1.52 & 97.77 \\
grandchild & 253 & 1.07 & 98.84 \\
other relatives, n.s & 90 & 0.38 & 99.22 \\
housemate/roomate & 20 & 0.08 & 99.31 \\
roomer/boarder/lodger & 6 & 0.03 & 99.33 \\
other nonrelatives & 158 & 0.67 & 100.00 \\
\hline Total & 23,623 & 100.00 &
\end{tabular}

\section{0-2018}

\begin{tabular}{r|rrr} 
relationship to household head & Freq. & Percent & Cum. \\
\hline head/householder & 1,041 & 4.26 & 4.26 \\
child & 22,004 & 90.14 & 94.41 \\
sibling & 537 & 2.20 & 96.61 \\
grandchild & 442 & 1.81 & 98.42 \\
other relatives, n.s & 156 & 0.64 & 99.06 \\
housemate/roomate & 31 & 0.13 & 99.18 \\
roomer/boarder/lodger & 6 & 0.02 & 99.21 \\
other nonrelatives & 193 & 0.79 & 100.00 \\
\hline Total & 24,410 & 100.00 &
\end{tabular}


Table A-2 Summary Statistics by Sex 1984-1989 Mele HSGs

\begin{tabular}{lrrrrr}
\hline Variable & Obs & Mean & Std. Dev. & Min & Max \\
\hline Enroll college & 10626 & .56 & .5 & 0 & 1 \\
UE state & 10626 & 6.53 & 2.06 & 2.2 & 15.2 \\
age & 10626 & 18.95 & .87 & 17 & 20 \\
age 17 & 10626 & .03 & .18 & 0 & 1 \\
age 18 & 10626 & .31 & .46 & 0 & 1 \\
age 19 & 10626 & .34 & .47 & 0 & 1 \\
age 20 & 10626 & .32 & .47 & 0 & 1 \\
income quart & 10626 & 2.97 & 1.01 & 1 & 4 \\
mom edu & 10626 & 3.64 & 1.41 & 0 & 6 \\
nsibs & 10626 & 1.38 & 1.24 & 0 & 9 \\
female & 10626 & 0 & 0 & 0 & 0 \\
white & 10626 & .81 & .39 & 0 & 1 \\
black & 10626 & .1 & .3 & 0 & 1 \\
hispanic & 10626 & .05 & .23 & 0 & 1 \\
others & 10626 & .04 & .18 & 0 & 1 \\
\hline
\end{tabular}

1984-1989 Female HSGs

\begin{tabular}{|c|c|c|c|c|c|}
\hline Variable & Obs & Mean & Std. Dev. & Min & Max \\
\hline Enroll college & 10842 & .6 & .49 & 0 & 1 \\
\hline UE state & 10842 & 6.5 & 2.08 & 2.2 & 15.2 \\
\hline age & 10842 & 18.87 & .88 & 17 & 20 \\
\hline age 17 & 10842 & .05 & .21 & 0 & 1 \\
\hline age 18 & 10842 & .33 & .47 & 0 & 1 \\
\hline age 19 & 10842 & .33 & .47 & 0 & 1 \\
\hline age 20 & 10842 & .29 & .45 & 0 & 1 \\
\hline income quart & 10842 & 2.9 & 1.04 & 1 & 4 \\
\hline mom edu & 10842 & 3.6 & 1.42 & 0 & 6 \\
\hline nsibs & 10842 & 1.44 & 1.27 & 0 & 9 \\
\hline female & 10842 & 1 & 0 & 1 & 1 \\
\hline white & 10842 & .79 & .41 & 0 & 1 \\
\hline black & 10842 & .12 & .32 & 0 & 1 \\
\hline hispanic & 10842 & .06 & .24 & 0 & 1 \\
\hline others & 10842 & .03 & .17 & 0 & 1 \\
\hline
\end{tabular}

(continued on the following page) 
(Table A-2 continued) 1990-1999 Male HSGs

\begin{tabular}{|c|c|c|c|c|c|}
\hline Variable & Obs & Mean & Std. Dev. & Min & Max \\
\hline Enroll college & 12492 & .62 & .48 & 0 & 1 \\
\hline UE state & 12492 & 5.82 & 1.62 & 2.4 & 11.5 \\
\hline age & 12492 & 18.98 & .85 & 17 & 20 \\
\hline age 17 & 12492 & .03 & .16 & 0 & 1 \\
\hline age 18 & 12492 & .29 & .45 & 0 & 1 \\
\hline age 19 & 12492 & .36 & .48 & 0 & 1 \\
\hline age 20 & 12492 & .32 & .47 & 0 & 1 \\
\hline income quart & 12492 & 2.97 & 1 & 1 & 4 \\
\hline mom edu & 12492 & 3.92 & 1.42 & 0 & 6 \\
\hline nsibs & 12492 & 1.24 & 1.14 & 0 & 9 \\
\hline female & 12492 & 0 & 0 & 0 & 0 \\
\hline white & 12492 & .77 & .42 & 0 & 1 \\
\hline black & 12492 & .09 & .29 & 0 & 1 \\
\hline hispanic & 12492 & .08 & .26 & 0 & 1 \\
\hline others & 12492 & .06 & .23 & 0 & 1 \\
\hline
\end{tabular}

1990-1999 Female HSGs

\begin{tabular}{|c|c|c|c|c|c|}
\hline Variable & Obs & Mean & Std. Dev. & Min & Max \\
\hline Enroll college & 12855 & .71 & .45 & 0 & 1 \\
\hline UE state & 12855 & 5.83 & 1.61 & 2.4 & 11.5 \\
\hline age & 12855 & 18.91 & .86 & 17 & 20 \\
\hline age 17 & 12855 & .03 & .18 & 0 & 1 \\
\hline age 18 & 12855 & .32 & .47 & 0 & 1 \\
\hline age 19 & 12855 & .35 & .48 & 0 & 1 \\
\hline age 20 & 12855 & .3 & .46 & 0 & 1 \\
\hline income quart & 12855 & 2.95 & 1.01 & 1 & 4 \\
\hline mom edu & 12855 & 3.9 & 1.43 & 0 & 6 \\
\hline nsibs & 12855 & 1.29 & 1.17 & 0 & 9 \\
\hline female & 12855 & 1 & 0 & 1 & 1 \\
\hline white & 12855 & .76 & .43 & 0 & 1 \\
\hline black & 12855 & .11 & .32 & 0 & 1 \\
\hline hispanic & 12855 & .08 & .27 & 0 & 1 \\
\hline others & 12855 & .05 & .21 & 0 & 1 \\
\hline
\end{tabular}

(continued on the following page) 
(Table A-2 continued)

2000-2009 Male HSGs

\begin{tabular}{|c|c|c|c|c|c|}
\hline Variable & Obs & Mean & Std. Dev. & Min & Max \\
\hline Enroll college & 11010 & .63 & .48 & 0 & 1 \\
\hline UE state & 11010 & 5.21 & 1.6 & 2.4 & 12.9 \\
\hline age & 11010 & 18.98 & .84 & 17 & 20 \\
\hline age 17 & 11010 & .02 & .15 & 0 & 1 \\
\hline age 18 & 11010 & .29 & .46 & 0 & 1 \\
\hline age 19 & 11010 & .36 & .48 & 0 & 1 \\
\hline age 20 & 11010 & .32 & .47 & 0 & 1 \\
\hline income quart & 11010 & 2.91 & 1 & 1 & 4 \\
\hline mom edu & 11010 & 4.22 & 1.42 & 0 & 6 \\
\hline nsibs & 11010 & 1.24 & 1.1 & 0 & 9 \\
\hline female & 11010 & 0 & 0 & 0 & 0 \\
\hline white & 11010 & .74 & .44 & 0 & 1 \\
\hline black & 11010 & .08 & .28 & 0 & 1 \\
\hline hispanic & 11010 & .11 & .32 & 0 & 1 \\
\hline others & 11010 & .07 & .25 & 0 & 1 \\
\hline
\end{tabular}

2000-2009 Female HSGs

\begin{tabular}{|c|c|c|c|c|c|}
\hline Variable & Obs & Mean & Std. Dev. & Min & Max \\
\hline Enroll college & 11102 & .74 & .44 & 0 & 1 \\
\hline UE state & 11102 & 5.21 & 1.58 & 2.4 & 12.9 \\
\hline age & 11102 & 18.91 & .86 & 17 & 20 \\
\hline age 17 & 11102 & .03 & .18 & 0 & 1 \\
\hline age 18 & 11102 & .32 & .47 & 0 & 1 \\
\hline age 19 & 11102 & .35 & .48 & 0 & 1 \\
\hline age 20 & 11102 & .29 & .46 & 0 & 1 \\
\hline income quart & 11102 & 2.85 & 1.03 & 1 & 4 \\
\hline mom edu & 11102 & 4.19 & 1.42 & 0 & 6 \\
\hline nsibs & 11102 & 1.26 & 1.13 & 0 & 9 \\
\hline female & 11102 & 1 & 0 & 1 & 1 \\
\hline white & 11102 & .71 & .45 & 0 & 1 \\
\hline black & 11102 & .1 & .31 & 0 & 1 \\
\hline hispanic & 11102 & .12 & .32 & 0 & 1 \\
\hline others & 11102 & .07 & .25 & 0 & 1 \\
\hline
\end{tabular}

(continued on the following page) 
(Table A-2 continued)

2010-2018 Male HSGs

\begin{tabular}{|c|c|c|c|c|c|}
\hline Variable & Obs & Mean & Std. Dev. & Min & Max \\
\hline Enroll college & 11109 & .62 & .48 & 0 & 1 \\
\hline UE state & 11109 & 6.66 & 2.36 & 2.3 & 13.5 \\
\hline age & 11109 & 18.98 & .86 & 17 & 20 \\
\hline age 17 & 11109 & .03 & .17 & 0 & 1 \\
\hline age 18 & 11109 & .28 & .45 & 0 & 1 \\
\hline age 19 & 11109 & .36 & .48 & 0 & 1 \\
\hline age 20 & 11109 & .33 & .47 & 0 & 1 \\
\hline income quart & 11109 & 2.79 & 1.02 & 1 & 4 \\
\hline mom edu & 11109 & 4.32 & 1.49 & 0 & 6 \\
\hline nsibs & 11109 & 1.28 & 1.12 & 0 & 9 \\
\hline female & 11109 & 0 & 0 & 0 & 0 \\
\hline white & 11109 & .63 & .48 & 0 & 1 \\
\hline black & 11109 & .1 & .3 & 0 & 1 \\
\hline hispanic & 11109 & .18 & .39 & 0 & 1 \\
\hline others & 11109 & .09 & .29 & 0 & 1 \\
\hline
\end{tabular}

2010-2018 Female HSGs

\begin{tabular}{|c|c|c|c|c|c|}
\hline Variable & Obs & Mean & Std. Dev. & Min & Max \\
\hline Enroll college & 10895 & .73 & .44 & 0 & 1 \\
\hline UE state & 10895 & 6.63 & 2.34 & 2.3 & 13.5 \\
\hline age & 10895 & 18.93 & .88 & 17 & 20 \\
\hline age 17 & 10895 & .04 & .19 & 0 & 1 \\
\hline age 18 & 10895 & .31 & .46 & 0 & 1 \\
\hline age 19 & 10895 & .34 & .47 & 0 & 1 \\
\hline age 20 & 10895 & .31 & .46 & 0 & 1 \\
\hline income quart & 10895 & 2.75 & 1.02 & 1 & 4 \\
\hline mom edu & 10895 & 4.34 & 1.47 & 0 & 6 \\
\hline nsibs & 10895 & 1.32 & 1.18 & 0 & 9 \\
\hline female & 10895 & 1 & 0 & 1 & 1 \\
\hline white & 10895 & .61 & .49 & 0 & 1 \\
\hline black & 10895 & .11 & .31 & 0 & 1 \\
\hline hispanic & 10895 & .19 & .39 & 0 & 1 \\
\hline others & 10895 & .09 & .29 & 0 & 1 \\
\hline
\end{tabular}

Source: IPUMS CPS; Bureau of Labor Statistics

Including samples who were aged 17-20 years old, graduated high school, and a child related to the head of the surveyed household. 
Table A-3 Effect of State Unemployment Rate on College Enrollment Probability (Clustered $\mathrm{SE})$

\begin{tabular}{|c|c|c|c|c|}
\hline & $\begin{array}{r}(1) \\
84-89\end{array}$ & $\begin{array}{r}(2) \\
90-99\end{array}$ & $\begin{array}{r}(3) \\
00-09\end{array}$ & $\begin{array}{r}(4) \\
10-18\end{array}$ \\
\hline UE_state & $\begin{array}{r}-0.00382 \\
(0.200)\end{array}$ & $\begin{array}{l}0.00148 \\
(0.704)\end{array}$ & $\begin{array}{l}0.00796 * * \\
(0.023)\end{array}$ & $\begin{array}{l}0.0120^{* * *} \\
(0.000)\end{array}$ \\
\hline age_18 & $\begin{array}{l}0.0629 * * * \\
(0.000)\end{array}$ & $\begin{array}{l}0.00317 \\
(0.861)\end{array}$ & $\begin{array}{l}0.138^{* * *} \\
(0.000)\end{array}$ & $\begin{array}{l}0.0919 * * * \\
(0.000)\end{array}$ \\
\hline age_19 & $\begin{array}{r}0.0174 \\
(0.325)\end{array}$ & $\begin{array}{l}-0.0436 * * \\
(0.023)\end{array}$ & $\begin{array}{l}0.107 * * * \\
(0.000)\end{array}$ & $\begin{array}{l}0.0617^{* * *} \\
(0.001)\end{array}$ \\
\hline age_20 & $\begin{array}{l}-0.0382^{* *} \\
(0.034)\end{array}$ & $\begin{array}{l}-0.0772 * * * \\
(0.000)\end{array}$ & $\begin{array}{l}0.0759 * * * \\
(0.004)\end{array}$ & $\begin{array}{r}0.0245 \\
(0.208)\end{array}$ \\
\hline _Iincome_qu_2 & $\begin{array}{l}0.0392 * * * \\
(0.005)\end{array}$ & $\begin{array}{l}0.0342 * * * \\
(0.001)\end{array}$ & $\begin{array}{l}0.0541 * * * \\
(0.000)\end{array}$ & $\begin{array}{r}0.0125 \\
(0.213)\end{array}$ \\
\hline _Iincome_qu_3 & $\begin{array}{l}0.0792 * * * \\
(0.000)\end{array}$ & $\begin{array}{l}0.0934 * * * \\
(0.000)\end{array}$ & $\begin{array}{l}0.118^{* * *} \\
(0.000)\end{array}$ & $\begin{array}{l}0.0650 * * * \\
(0.000)\end{array}$ \\
\hline _Iincome_qu_4 & $\begin{array}{l}0.169 * * * \\
(0.000)\end{array}$ & $\begin{array}{c}0.196 * * * \\
(0.000)\end{array}$ & $\begin{array}{l}0.202^{* * *} \\
(0.000)\end{array}$ & $\begin{array}{l}0.164^{* * *} \\
(0.000)\end{array}$ \\
\hline mom_edu & $\begin{array}{l}0.0936 * * * \\
(0.000)\end{array}$ & $\begin{array}{l}0.0747^{* * *} \\
(0.000)\end{array}$ & $\begin{array}{l}0.0668 * * * \\
(0.000)\end{array}$ & $\begin{array}{l}0.0618^{* * *} \\
(0.000)\end{array}$ \\
\hline nsibs & $\begin{array}{l}-0.0100 * * * \\
(0.001)\end{array}$ & $\begin{array}{r}0.000524 \\
(0.881)\end{array}$ & $\begin{array}{r}0.000603 \\
(0.877)\end{array}$ & $\begin{array}{r}-0.000672 \\
(0.820)\end{array}$ \\
\hline female & $\begin{array}{l}0.0504 * * * \\
(0.000)\end{array}$ & $\begin{array}{l}0.0878^{* * *} \\
(0.000)\end{array}$ & $\begin{array}{l}0.111 * * * \\
(0.000)\end{array}$ & $\begin{array}{l}0.108^{* * *} \\
(0.000)\end{array}$ \\
\hline black & $\begin{array}{l}-0.0606 * * * \\
(0.001)\end{array}$ & $\begin{array}{l}-0.0488^{* * *} \\
(0.000)\end{array}$ & $\begin{array}{l}-0.0230 * \\
(0.083)\end{array}$ & $\begin{array}{l}-0.0168 \\
(0.353)\end{array}$ \\
\hline hispanic & $\begin{array}{r}0.0221 \\
(0.236)\end{array}$ & $\begin{array}{l}0.0339 * * \\
(0.014)\end{array}$ & $\begin{array}{l}0.00293 \\
(0.857)\end{array}$ & $\begin{array}{l}0.0670 * * * \\
(0.000)\end{array}$ \\
\hline others & $\begin{array}{c}0.0853 * \\
(0.071)\end{array}$ & $\begin{array}{c}0.0720^{*} \\
(0.057)\end{array}$ & $\begin{array}{r}0.0462 \\
(0.176)\end{array}$ & $\begin{array}{l}0.0563 * * \\
(0.013)\end{array}$ \\
\hline $\mathrm{N}$ & 21468 & 25347 & 22112 & 22004 \\
\hline
\end{tabular}

$\mathrm{p}$-values in parentheses

Source: IPUMS CPS

Including samples who were age 17-20 years old, graduated high school, and a child related to the head of the household.

Estimated by Probit and average marginal effects (AME) are reported.

Standard errors are clustered at state level.

State UE Effect on College Enrollment

$* \mathrm{p}<0.10, * * \mathrm{p}<0.05, * * * \mathrm{p}<0.010$ 
Table A-4 Effect of State Unemployment Rate on College Enrollment Probability by Sex (Clustered SE)

\begin{tabular}{|c|c|c|c|c|c|c|c|c|}
\hline & $\begin{array}{r}(1) \\
84-89 M\end{array}$ & $\begin{array}{r}(2) \\
84-89 \mathrm{~F}\end{array}$ & $\begin{array}{r}(3) \\
90-99 M\end{array}$ & $\begin{array}{r}(4) \\
90-99 \mathrm{~F}\end{array}$ & $\begin{array}{r}(5) \\
00-09 M\end{array}$ & $\begin{array}{r}(6) \\
00-09 \mathrm{~F}\end{array}$ & $\begin{array}{r}(7) \\
10-18 \mathrm{M}\end{array}$ & $\begin{array}{r}(8) \\
10-18 \mathrm{~F}\end{array}$ \\
\hline UE_state & $\begin{array}{r}-0.00268 \\
(0.510)\end{array}$ & $\begin{array}{r}-0.00489 \\
(0.113)\end{array}$ & $\begin{array}{l}0.00433 \\
(0.383)\end{array}$ & $\begin{array}{r}-0.00131 \\
(0.715)\end{array}$ & $\begin{array}{l}0.0100 * * \\
(0.032)\end{array}$ & $\begin{array}{l}0.00605 * \\
(0.096)\end{array}$ & $\begin{array}{l}0.0133^{* * *} \\
(0.000)\end{array}$ & $\begin{array}{l}0.0106 * * * \\
(0.000)\end{array}$ \\
\hline age_18 & $\begin{array}{l}0.0752 * * * \\
(0.002)\end{array}$ & $\begin{array}{l}0.0531 * * \\
(0.011)\end{array}$ & $\begin{array}{l}-0.0174 \\
(0.485)\end{array}$ & $\begin{array}{r}0.0157 \\
(0.488)\end{array}$ & $\begin{array}{l}0.140 * * * \\
(0.000)\end{array}$ & $\begin{array}{c}0.131^{* * *} \\
(0.000)\end{array}$ & $\begin{array}{l}0.0638 * * \\
(0.012)\end{array}$ & $\begin{array}{l}0.109 * * * \\
(0.000)\end{array}$ \\
\hline age_19 & $\begin{array}{l}0.00533 \\
(0.843)\end{array}$ & $\begin{array}{r}0.0306 \\
(0.101)\end{array}$ & $\begin{array}{l}-0.0727 * * * \\
(0.005)\end{array}$ & $\begin{array}{l}-0.0236 \\
(0.321)\end{array}$ & $\begin{array}{l}0.0947 * * \\
(0.014)\end{array}$ & $\begin{array}{c}0.114^{* * *} \\
(0.000)\end{array}$ & $\begin{array}{r}0.0334 \\
(0.203)\end{array}$ & $\begin{array}{l}0.0796 * * * \\
(0.000)\end{array}$ \\
\hline age_20 & $\begin{array}{l}-0.0442 * \\
(0.100)\end{array}$ & $\begin{array}{l}-0.0312 * \\
(0.075)\end{array}$ & $\begin{array}{l}-0.111^{* * *} \\
(0.000)\end{array}$ & $\begin{array}{l}-0.0527^{* *} \\
(0.019)\end{array}$ & $\begin{array}{c}0.0618^{*} \\
(0.096)\end{array}$ & $\begin{array}{l}0.0847^{* * * *} \\
(0.000)\end{array}$ & $\begin{array}{l}-0.0160 \\
(0.564)\end{array}$ & $\begin{array}{l}0.0545^{* * *} \\
(0.009)\end{array}$ \\
\hline _Iincome_qu_2 & $\begin{array}{r}0.0187 \\
(0.277)\end{array}$ & $\begin{array}{l}0.0580 * * * \\
(0.001)\end{array}$ & $\begin{array}{l}0.0284 * * \\
(0.036)\end{array}$ & $\begin{array}{l}0.0388 * * * \\
(0.004)\end{array}$ & $\begin{array}{l}0.0514 * * * \\
(0.004)\end{array}$ & $\begin{array}{l}0.0555^{* * *} \\
(0.000)\end{array}$ & $\begin{array}{r}0.0139 \\
(0.274)\end{array}$ & $\begin{array}{r}0.0109 \\
(0.408)\end{array}$ \\
\hline _Iincome_qu_3 & $\begin{array}{l}0.0891 * * * \\
(0.000)\end{array}$ & $\begin{array}{l}0.0693 * * * \\
(0.000)\end{array}$ & $\begin{array}{l}0.0918 * * * \\
(0.000)\end{array}$ & $\begin{array}{l}0.0939 * * * \\
(0.000)\end{array}$ & $\begin{array}{l}0.125^{* * *} \\
(0.000)\end{array}$ & $\begin{array}{l}0.110^{* * *} \\
(0.000)\end{array}$ & $\begin{array}{l}0.0640 * * * \\
(0.000)\end{array}$ & $\begin{array}{l}0.0652 * * * \\
(0.000)\end{array}$ \\
\hline _Iincome_qu_4 & $\begin{array}{l}0.179 * * * \\
(0.000)\end{array}$ & $\begin{array}{l}0.157^{* * *} \\
(0.000)\end{array}$ & $\begin{array}{l}0.209 * * * \\
(0.000)\end{array}$ & $\begin{array}{c}0.182^{* * *} \\
(0.000)\end{array}$ & $\begin{array}{c}0.212^{* * *} \\
(0.000)\end{array}$ & $\begin{array}{l}0.193^{* * *} \\
(0.000)\end{array}$ & $\begin{array}{c}0.182^{* * *} \\
(0.000)\end{array}$ & $\begin{array}{c}0.145^{* * *} \\
(0.000)\end{array}$ \\
\hline mom_edu & $\begin{array}{l}0.0898 * * * \\
(0.000)\end{array}$ & $\begin{array}{l}0.0975 * * * \\
(0.000)\end{array}$ & $\begin{array}{l}0.0771 * * * \\
(0.000)\end{array}$ & $\begin{array}{l}0.0722 * * * \\
(0.000)\end{array}$ & $\begin{array}{l}0.0726 * * * \\
(0.000)\end{array}$ & $\begin{array}{l}0.0607 * * * \\
(0.000)\end{array}$ & $\begin{array}{l}0.0647 * * * \\
(0.000)\end{array}$ & $\begin{array}{l}0.0587^{* * *} \\
(0.000)\end{array}$ \\
\hline nsibs & $\begin{array}{l}-0.0103 * * \\
(0.043)\end{array}$ & $\begin{array}{c}-0.00982^{* * *} \\
(0.008)\end{array}$ & $\begin{array}{r}-0.00225 \\
(0.707)\end{array}$ & $\begin{array}{l}0.00310 \\
(0.489)\end{array}$ & $\begin{array}{r}0.000857 \\
(0.897)\end{array}$ & $\begin{array}{r}0.000416 \\
(0.914)\end{array}$ & $\begin{array}{l}0.00491 \\
(0.257)\end{array}$ & $\begin{array}{r}-0.00517 \\
(0.163)\end{array}$ \\
\hline black & $\begin{array}{l}-0.0754 * * * \\
(0.000)\end{array}$ & $\begin{array}{l}-0.0489 * * \\
(0.017)\end{array}$ & $\begin{array}{l}-0.0451 * * * \\
(0.008)\end{array}$ & $\begin{array}{l}-0.0513^{* * *} \\
(0.000)\end{array}$ & $\begin{array}{r}-0.00839 \\
(0.700)\end{array}$ & $\begin{array}{l}-0.0340 * * \\
(0.028)\end{array}$ & $\begin{array}{l}-0.0140 \\
(0.578)\end{array}$ & $\begin{array}{l}-0.0204 \\
(0.238)\end{array}$ \\
\hline hispanic & $\begin{array}{r}0.0315 \\
(0.225)\end{array}$ & $\begin{array}{r}0.0159 \\
(0.545)\end{array}$ & $\begin{array}{r}0.0297 \\
(0.144)\end{array}$ & $\begin{array}{l}0.0372 * * \\
(0.024)\end{array}$ & $\begin{array}{l}0.00313 \\
(0.874)\end{array}$ & $\begin{array}{l}0.00204 \\
(0.903)\end{array}$ & $\begin{array}{l}0.0768 * * * \\
(0.000)\end{array}$ & $\begin{array}{l}0.0570 * * * \\
(0.002)\end{array}$ \\
\hline others & $\begin{array}{r}0.0762 \\
(0.140)\end{array}$ & $\begin{array}{l}0.0969 * * \\
(0.041)\end{array}$ & $\begin{array}{c}0.0793 * \\
(0.051)\end{array}$ & $\begin{array}{c}0.0638^{*} \\
(0.095)\end{array}$ & $\begin{array}{l}0.0950 * * \\
(0.013)\end{array}$ & $\begin{array}{r}-0.00113 \\
(0.971)\end{array}$ & $\begin{array}{l}0.0949 * * * \\
(0.003)\end{array}$ & $\begin{array}{r}0.0193 \\
(0.293)\end{array}$ \\
\hline $\mathrm{N}$ & 10626 & 10842 & 12492 & 12855 & 11010 & 11102 & 11109 & 10895 \\
\hline
\end{tabular}

p-values in parentheses

Source: IPUMS CPS

Including samples who were age 17-20 years old, graduated high school, and a child related to the head of the household.

Estimated by Probit and average marginal effects (AME) are reported.

Standard errors are clustered at state level.

State UE Effect on College Enrollment by Gender

$* \mathrm{p}<0.10, * * \mathrm{p}<0.05, * * * \mathrm{p}<0.010$ 
Table A-5 Effect of State Unemployment Rate on College Enrollment Probability Among Races/Ethnicity Groups (Clustered SE)

\begin{tabular}{|c|c|c|c|c|}
\hline & $\begin{array}{r}(1) \\
\text { White }\end{array}$ & $\begin{array}{r}(2) \\
\text { Black }\end{array}$ & $\begin{array}{r}(3) \\
\text { Hispanic }\end{array}$ & $\begin{array}{r}(4) \\
\text { Others }\end{array}$ \\
\hline UE_state & $\begin{array}{r}-0.00310 \\
(0.297)\end{array}$ & $\begin{array}{r}-0.000605 \\
(0.929)\end{array}$ & $\begin{array}{l}-0.0147 * \\
(0.084)\end{array}$ & $\begin{array}{l}-0.0145 \\
(0.569)\end{array}$ \\
\hline age_18 & $\begin{array}{l}0.0772 * * * \\
(0.000)\end{array}$ & $\begin{array}{r}0.0194 \\
(0.700)\end{array}$ & $\begin{array}{r}0.0137 \\
(0.905)\end{array}$ & $\begin{array}{l}-0.0188 \\
(0.770)\end{array}$ \\
\hline age_19 & $\begin{array}{c}0.0293 * \\
(0.095)\end{array}$ & $\begin{array}{l}-0.0327 \\
(0.532)\end{array}$ & $\begin{array}{l}-0.0150 \\
(0.884)\end{array}$ & $\begin{array}{l}-0.0542 \\
(0.451)\end{array}$ \\
\hline age_20 & $\begin{array}{l}-0.0308 \\
(0.108)\end{array}$ & $\begin{array}{l}-0.0569 \\
(0.275)\end{array}$ & $\begin{array}{l}-0.0662 \\
(0.501)\end{array}$ & $\begin{array}{c}-0.114^{*} \\
(0.084)\end{array}$ \\
\hline _Iincome_qu_2 & $\begin{array}{l}0.0393 * * \\
(0.040)\end{array}$ & $\begin{array}{l}0.0959 * * * \\
(0.000)\end{array}$ & $\begin{array}{l}-0.0220 \\
(0.584)\end{array}$ & $\begin{array}{c}0.100^{* *} \\
(0.025)\end{array}$ \\
\hline _Iincome_qu_3 & $\begin{array}{l}0.0882 * * * \\
(0.000)\end{array}$ & $\begin{array}{l}0.0736^{* *} \\
(0.026)\end{array}$ & $\begin{array}{c}0.0558^{*} \\
(0.063)\end{array}$ & $\begin{array}{l}0.138^{* * *} \\
(0.009)\end{array}$ \\
\hline _Iincome_qu_4 & $\begin{array}{c}0.177^{* * *} \\
(0.000)\end{array}$ & $\begin{array}{l}0.162^{* * *} \\
(0.000)\end{array}$ & $\begin{array}{r}0.0780 \\
(0.169)\end{array}$ & $\begin{array}{l}0.174 * * * \\
(0.004)\end{array}$ \\
\hline mom_edu & $\begin{array}{c}0.100 * * * \\
(0.000)\end{array}$ & $\begin{array}{l}0.0818^{* * *} \\
(0.000)\end{array}$ & $\begin{array}{l}0.0694 * * * \\
(0.000)\end{array}$ & $\begin{array}{l}0.0486 * * * \\
(0.000)\end{array}$ \\
\hline nsibs & $\begin{array}{c}-0.00972 * * \\
(0.011)\end{array}$ & $\begin{array}{l}-0.0238^{* * *} \\
(0.000)\end{array}$ & $\begin{array}{c}-0.0000826 \\
(0.993)\end{array}$ & $\begin{array}{l}-0.0231 \\
(0.164)\end{array}$ \\
\hline female & $\begin{array}{l}0.0472 * * * \\
(0.000)\end{array}$ & $\begin{array}{l}0.0775^{* * *} \\
(0.000)\end{array}$ & $\begin{array}{r}0.0299 \\
(0.421)\end{array}$ & $\begin{array}{l}0.0763^{* * *} \\
(0.003)\end{array}$ \\
\hline $\mathrm{N}$ & 17163 & 2334 & 1252 & 719 \\
\hline
\end{tabular}

\begin{tabular}{|c|c|c|c|c|}
\hline & $\begin{array}{r}(1) \\
\text { White }\end{array}$ & $\begin{array}{r}(2) \\
\text { Black }\end{array}$ & $\begin{array}{r}(3) \\
\text { Hispanic }\end{array}$ & $\begin{array}{r}(4) \\
\text { Others }\end{array}$ \\
\hline UE_state & $\begin{array}{c}-0.00160 \\
(0.706)\end{array}$ & $\begin{array}{r}-0.000437 \\
(0.945)\end{array}$ & $\begin{array}{l}0.0237 * * * \\
(0.000)\end{array}$ & $\begin{array}{r}0.0215 \\
(0.104)\end{array}$ \\
\hline age_18 & $\begin{array}{l}0.00777 \\
(0.765)\end{array}$ & $\begin{array}{l}-0.0374 \\
(0.370)\end{array}$ & $\begin{array}{r}-0.00117 \\
(0.983)\end{array}$ & $\begin{array}{r}0.0170 \\
(0.641)\end{array}$ \\
\hline age_19 & $\begin{array}{l}-0.0426^{*} \\
(0.092)\end{array}$ & $\begin{array}{l}-0.0555 \\
(0.235)\end{array}$ & $\begin{array}{l}-0.0616 \\
(0.323)\end{array}$ & $\begin{array}{l}-0.0166 \\
(0.664)\end{array}$ \\
\hline age_20 & $\begin{array}{l}-0.0725^{* * *} \\
(0.007)\end{array}$ & $\begin{array}{l}-0.129 * * * \\
(0.004)\end{array}$ & $\begin{array}{l}-0.0720 \\
(0.190)\end{array}$ & $\begin{array}{l}-0.0665^{*} \\
(0.075)\end{array}$ \\
\hline _Iincome_qu_2 & $\begin{array}{l}0.0357 * * \\
(0.015)\end{array}$ & $\begin{array}{l}0.0669 * * * \\
(0.004)\end{array}$ & $\begin{array}{l}0.0507 * * \\
(0.048)\end{array}$ & $\begin{array}{l}0.00545 \\
(0.876)\end{array}$ \\
\hline _Iincome_qu_3 & $\begin{array}{l}0.0971^{* * *} \\
(0.000)\end{array}$ & $\begin{array}{c}0.154^{* * *} \\
(0.000)\end{array}$ & $\begin{array}{l}0.122^{* * *} \\
(0.000)\end{array}$ & $\begin{array}{l}0.00804 \\
(0.838)\end{array}$ \\
\hline _Iincome_qu_4 & $\begin{array}{c}0.197^{* * *} \\
(0.000)\end{array}$ & $\begin{array}{l}0.251^{* * *} \\
(0.000)\end{array}$ & $\begin{array}{c}0.187 * * * \\
(0.000)\end{array}$ & $\begin{array}{l}0.114 * * * \\
(0.000)\end{array}$ \\
\hline mom_edu & $\begin{array}{l}0.0824 * * * \\
(0.000)\end{array}$ & $\begin{array}{l}0.0726^{* * *} \\
(0.000)\end{array}$ & $\begin{array}{l}0.0380^{* * *} \\
(0.001)\end{array}$ & $\begin{array}{l}0.0498^{* * *} \\
(0.000)\end{array}$ \\
\hline nsibs & $\begin{array}{r}0.000125 \\
(0.980)\end{array}$ & $\begin{array}{l}-0.0110 \\
(0.229)\end{array}$ & $\begin{array}{r}-0.00197 \\
(0.769)\end{array}$ & $\begin{array}{r}-0.00732 \\
(0.544)\end{array}$ \\
\hline female & $\begin{array}{l}0.0872^{* * *} \\
(0.000)\end{array}$ & $\begin{array}{l}0.0876^{* * *} \\
(0.000)\end{array}$ & $\begin{array}{l}0.110^{* * *} \\
(0.000)\end{array}$ & $\begin{array}{l}0.0695 * * * \\
(0.000)\end{array}$ \\
\hline $\mathrm{N}$ & 19371 & 2643 & 1987 & 1344 \\
\hline
\end{tabular}

$2000-2009$

$2010-2018$

\begin{tabular}{|c|c|c|c|c|c|c|c|c|c|}
\hline & $\begin{array}{r}(1) \\
\text { White }\end{array}$ & $\begin{array}{r}(2) \\
\text { Black }\end{array}$ & $\begin{array}{r}(3) \\
\text { Hispanic }\end{array}$ & $\begin{array}{r}(4) \\
\text { Others }\end{array}$ & & $\begin{array}{r}(1) \\
\text { White }\end{array}$ & $\begin{array}{r}(2) \\
\text { Black }\end{array}$ & $\begin{array}{r}(3) \\
\text { Hispanic }\end{array}$ & $\begin{array}{r}(4) \\
\text { Others }\end{array}$ \\
\hline UE_state & $\begin{array}{l}0.00736 * * \\
(0.042)\end{array}$ & $\begin{array}{c}0.0104 * \\
(0.100)\end{array}$ & $\begin{array}{l}0.00601 \\
(0.373)\end{array}$ & $\begin{array}{r}0.0117 \\
(0.453)\end{array}$ & UE_state & $\begin{array}{l}0.0128^{* * *} \\
(0.000)\end{array}$ & $\begin{array}{l}0.0110^{* *} \\
(0.025)\end{array}$ & $\begin{array}{l}0.00765 \\
(0.120)\end{array}$ & $\begin{array}{l}0.0185^{* * *} \\
(0.000)\end{array}$ \\
\hline age_18 & $\begin{array}{l}0.168^{* * *} \\
(0.000)\end{array}$ & $\begin{array}{r}0.0993 \\
(0.146)\end{array}$ & $\begin{array}{r}0.0455 \\
(0.366)\end{array}$ & $\begin{array}{l}0.124 * * \\
(0.013)\end{array}$ & age_18 & $\begin{array}{l}0.0945^{* * *} \\
(0.000)\end{array}$ & $\begin{array}{l}0.119 * * \\
(0.013)\end{array}$ & $\begin{array}{l}0.0623 * * \\
(0.034)\end{array}$ & $\begin{array}{r}0.0722 \\
(0.143)\end{array}$ \\
\hline age_19 & $\begin{array}{l}0.142^{* * *} \\
(0.000)\end{array}$ & $\begin{array}{r}0.0713 \\
(0.269)\end{array}$ & $\begin{array}{l}-0.0191 \\
(0.666)\end{array}$ & $\begin{array}{l}0.0907 * \\
(0.083)\end{array}$ & age_19 & $\begin{array}{l}0.0645^{* *} \\
(0.017)\end{array}$ & $\begin{array}{c}0.0953^{*} \\
(0.057)\end{array}$ & $\begin{array}{r}0.0294 \\
(0.425)\end{array}$ & $\begin{array}{r}0.0357 \\
(0.396)\end{array}$ \\
\hline age_20 & $\begin{array}{l}0.110^{* * *} \\
(0.000)\end{array}$ & $\begin{array}{r}0.0547 \\
(0.430)\end{array}$ & $\begin{array}{l}-0.0672 \\
(0.114)\end{array}$ & $\begin{array}{r}0.0698 \\
(0.206)\end{array}$ & age_20 & $\begin{array}{r}0.0277 \\
(0.357)\end{array}$ & $\begin{array}{r}0.0739 \\
(0.102)\end{array}$ & $\begin{array}{l}-0.0336 \\
(0.158)\end{array}$ & $\begin{array}{r}0.0238 \\
(0.565)\end{array}$ \\
\hline _Iincome_qu_2 & $\begin{array}{l}0.0669 * * * \\
(0.000)\end{array}$ & $\begin{array}{r}0.0120 \\
(0.649)\end{array}$ & $\begin{array}{l}0.0792 * * * \\
(0.000)\end{array}$ & $\begin{array}{l}0.0651^{*} \\
(0.094)\end{array}$ & _Iincome_qu_2 & $\begin{array}{r}0.0200 \\
(0.176)\end{array}$ & $\begin{array}{r}-0.00103 \\
(0.971)\end{array}$ & $\begin{array}{r}0.0221 \\
(0.313)\end{array}$ & $\begin{array}{r}0.0367 \\
(0.298)\end{array}$ \\
\hline _Iincome_qu_3 & $\begin{array}{l}0.129 * * * \\
(0.000)\end{array}$ & $\begin{array}{l}0.0927 * * * \\
(0.004)\end{array}$ & $\begin{array}{l}0.139 * * * \\
(0.000)\end{array}$ & $\begin{array}{l}0.138^{* * *} \\
(0.005)\end{array}$ & _Iincome_qu_3 & $\begin{array}{l}0.0837 * * * \\
(0.000)\end{array}$ & $\begin{array}{l}0.0847 * * * \\
(0.002)\end{array}$ & $\begin{array}{r}0.0461 \\
(0.131)\end{array}$ & $\begin{array}{r}0.0492 \\
(0.270)\end{array}$ \\
\hline _Iincome_qu_4 & $\begin{array}{l}0.206 * * * \\
(0.000)\end{array}$ & $\begin{array}{c}0.192^{* * *} \\
(0.000)\end{array}$ & $\begin{array}{l}0.223^{* * *} \\
(0.000)\end{array}$ & $\begin{array}{c}0.225^{* * *} \\
(0.000)\end{array}$ & _Iincome_qu_4 & $\begin{array}{l}0.179 * * * \\
(0.000)\end{array}$ & $\begin{array}{l}0.159 * * * \\
(0.002)\end{array}$ & $\begin{array}{l}0.124 * * * \\
(0.000)\end{array}$ & $\begin{array}{l}0.120^{* * *} \\
(0.003)\end{array}$ \\
\hline mom_edu & $\begin{array}{l}0.0745^{* * *} \\
(0.000)\end{array}$ & $\begin{array}{l}0.0759 * * * \\
(0.000)\end{array}$ & $\begin{array}{l}0.0434 * * * \\
(0.000)\end{array}$ & $\begin{array}{l}0.0366^{* * *} \\
(0.000)\end{array}$ & mom_edu & $\begin{array}{l}0.0759 * * * \\
(0.000)\end{array}$ & $\begin{array}{l}0.0497^{* * *} \\
(0.000)\end{array}$ & $\begin{array}{l}0.0419 * * * \\
(0.000)\end{array}$ & $\begin{array}{l}0.0468 * * * \\
(0.000)\end{array}$ \\
\hline nsibs & $\begin{array}{l}0.00366 \\
(0.371)\end{array}$ & $\begin{array}{r}-0.00942 \\
(0.310)\end{array}$ & $\begin{array}{c}-0.0121 \\
(0.257)\end{array}$ & $\begin{array}{c}-0.0117 \\
(0.361)\end{array}$ & nsibs & $\begin{array}{r}-0.000603 \\
(0.873)\end{array}$ & $\begin{array}{l}0.00136 \\
(0.877)\end{array}$ & $\begin{array}{l}-0.0106 \\
(0.201)\end{array}$ & $\begin{array}{r}-0.00612 \\
(0.329)\end{array}$ \\
\hline female & $\begin{array}{l}0.118^{* * *} \\
(0.000)\end{array}$ & $\begin{array}{l}0.0981 * * * \\
(0.000)\end{array}$ & $\begin{array}{l}0.127^{* * *} \\
(0.000)\end{array}$ & $\begin{array}{r}0.0278 \\
(0.187)\end{array}$ & female & $\begin{array}{l}0.115^{* * *} \\
(0.000)\end{array}$ & $\begin{array}{c}0.116^{* * *} \\
(0.000)\end{array}$ & $\begin{array}{l}0.106 * * * \\
(0.000)\end{array}$ & $\begin{array}{l}0.0454 * \\
(0.051)\end{array}$ \\
\hline $\mathrm{N}$ & 16033 & 2072 & 2530 & 1476 & $\mathrm{~N}$ & 13633 & 2299 & 4051 & 2021 \\
\hline
\end{tabular}


